\title{
歯科用陶材焼成時における収縮とポロシティー
}

九州歯科大学大学院菌学研究科歯科補経学第 2 柇攻 (指導 : 内田㻖也教授)

林恩信

倨年 55 年 12 月 26 日受付

本論文の要旨は，昭和55年 6 月15日第40回九州粜科学会総会において発表した。

\section{Firing Shrinkage and Porosity of Dental Porcelain}

\author{
En-Hsing Lin \\ Second Department of Prosthetic Dentistry (Director : Prof. Yasunari Uchida) \\ Kyushu Dental College, Kitakyushu, Japan
}

Fixed superiorities of dental porcelain have been evaluated in many respects since it was introduced in dentistry almost a century ago. It seems, however, that porcelain has been used less frequently for crown and bridge work than dental resins. One of the causes for it may be the difficulty of porcelain to successfully compensate for its inherent large shrinkage during firing. For the best clinical performance with porcelain, it would be essential to complete the whole process in a way to minimize the shrinkage and porosity.

In the present paper, occurrences of shrinkage and porosity of dental porcelain were investigated in relation to thickness of porcelain, kind of mixing medium, condition of condensation, firing atmosphere, firing temperature and holding period at a particular temperature. The material used for all the experiments was one and the same kind of air-firing porcelain.

The results were as follows :

1. A mechanical condenser was experimentally made, in which the vibration is generated by the deviation from the uniform revolution of a round plate connected to the axis of the motor.

In any thickness of the specimen, the void space was reduced, or the degree of condensation became higher, as the number of the motor revolution increased within a certain limit.

2. When the specimen was fired at the temperature recommended by the manufacturer $\left(900^{\circ} \mathrm{C}\right)$ in air or in vacuum, firing shrinkage decreased significantly with an increase in the degree of condensation, while no changes were found in porosity.

3. Under the same degree of condensation, both shrinkage and porosity generally showed a tendency to increase with an increase in thickness of specimen.

4. There were no statistical differences in shrinkage and porosity between the 
specimens fired in air and in vacuum at the temperatures not higher than $900^{\circ} \mathrm{C}$.

5. When the firing process was carried out at the temperatures higher than $900^{\circ} \mathrm{C}$, vacuum-fired specimen showed higher shrinkage and lower porosity than air-fired one.

6. In comparison of the effect of firing temperature on the shrinkage and porosity, shrinkage increased and porosity decreased significantly in vacuum-firing, as the firing temperature increased above $900^{\circ} \mathrm{C}$. In air-firing, on the other hand, both shrinkage and porosity appeared constant above $900^{\circ} \mathrm{C}$, probably because the residual voids inside the specimen were sealed by the glazed surface.

7. As the holding period was prolonged at $900^{\circ} \mathrm{C}$, the firing shrinkage slightly increased and porosity slightly decreased both in air and in vacuum.

\section{緒言}

近代粤科補緅では審美的要素を十分に考慮した修復が 行われる傾向がみられ，修復物を天然菌汇酷似させるた めの材料や技術の開発が数多くなされ，驚異的な進歩を とげつつある。中でも菌科用陶枋は，審美的にも物性的 にもすぐれた材料として高く評価されている。こて20年 間は，高度経済成長の影響もあって罂材に対する患者の 要求が多く, 臨床に抢けるその利用頻度に目をみはるも のがあった。しかしながら，歯科用陶材には基礎理論的 にも，臨床技術的にもまだ解決されていない問題点が数 多く残されている，そのなかでも，焼成過程における陶 材の大きな収縮が最終的な形態や色調に微妙な影響をお よぼす点については深く興味が持たれるところである。 臨休における陶材修復物の製作過程を大別すると， （1）形成過程，（2）烧結過程の 2 つである. 陶材は焼 成中に陶材粒子の非溶融部を核とし，溶融部ガラス質を 地とする一塊の有核組織をつくるので，焼成前に含まれ ていた水分や空気がほとんどなくなり，その水分や空気 が占めていた体積だけ収縮する(1ー6)といわ机ている。乙 の収縮は前述した 2 つ過程にみられる多くの因子?-9! によって影響される.すなわち，コンデンス方法，鲀材 粒子の大きさ，焼成雲囲気，焼成温度などが変わると収 縮の程度も大きく変動する。

陶材の収縮に関する基礎的研究注比較的少なく，Gill $\left.(1931)^{10}\right),(1932)^{111}$, Clark $(1935)^{121}$, Skinner and Fitzgerald (1938) ${ }^{13}$, Hodson (1959) ${ }^{14}$ ', Baker

$(1950)^{15)},(1960)^{16)}$, Felcher $(1932)^{172},(1934)$ ${ }^{18}$ ，松本 $(1962)^{19}$ ， 追立 $\left.(1973)^{9}\right)$ らの研究報告が あるに過ぎない。とのうち，Gill10,11，Clark ${ }^{12) ，}$ Skinner ${ }^{13)}$ および Felcher ${ }^{171}$ の研究では，いずれも 陶材の材質打よびコンデンス法の相違が烧成時収縮に及
ぼす影響について報告している．また，Hodson ${ }^{14)}$ は 陶材粉末の粒度とコンデンス効果の関係および焼結条 件の相違が収縮率に及ぼす影響について調べており， Baker ${ }^{15}$ ) は各種コンデンス法についての検討をしてい る。松本 ${ }^{19)}$ は陶材コンデンス時に使用した陶材泥の混 水比が焼成時の収縮に影響を及ぼすと述へてている。さら に，追立 ${ }^{9}$ は種々の組成の陶材について，焼成時の収縮 を検討している。これらの研究では, 焼成時の収縮とい うものがどのようなかたちで起てっているかについて は，何ら検討されておらず,部分的な実験報告がなされて いるに過ぎない，著者はコンデンス法, 試験片の厚さ, 焼成雲囲気, 陶材混和液の種類, 焼成温度, 繫留時間な ぞの諸因子をいろいろに変えた組み合わせで缸材を焼成 し，てれらの諸因子が，焼成時の陶材の収縮にどのよう な影響を与えるかを追求した。なおまた，陶材の仪縮に ともなうポロシティーの変化についても測定を行った。

\section{実験材料ならびに試耠片の作製}

\section{1. 奏験材料}

本実験に使用した材料は，市販されているコロンバス 社製の大気焼成用アルミナス陶材 Steel's aluminous porcelain の Dentin 色, $\mathrm{D}_{5}$ である。

2. 試験片作製法

1) テフロン型とスベーサー

試験片を作製するため，Fig.1 亿示すような円柱状 の孔をもつ分割テフロン型と 3 種類のスペーサーを製作 した，分割テフロン型は, 内径 $10 \mathrm{~mm}$, 高さ $10 \mathrm{~mm}$ で, スペーサーの直径はいずれも $10 \mathrm{~mm}$ ，高さ $7.8 ， 8.3$, $8.8 \mathrm{~mm}$ の 3 通りになっている.コンデンス後の陶材生 型をきれいにとりだすため, 曆さ $0.2 \mathrm{~mm}$ のビニール・ テープをスベーサーの表面にはりつけた。試験片の厚さ は，スベーサーを変えるてとによって $2.0 ， 1.5 ， 1.0$ 


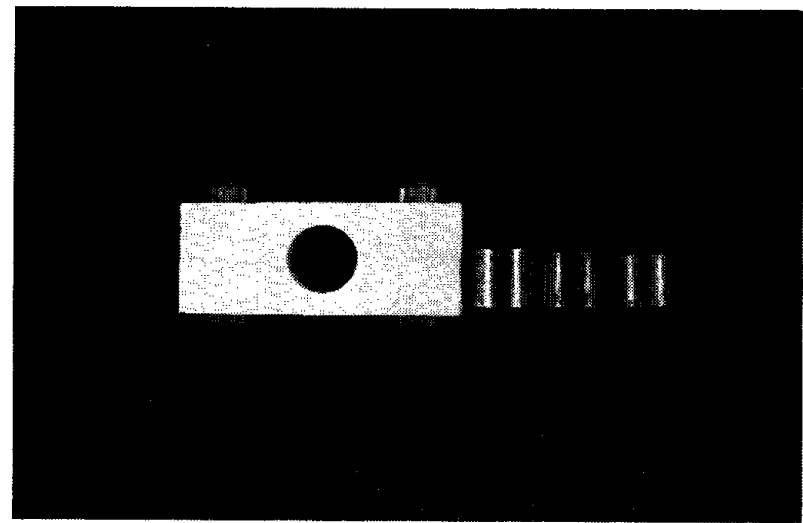

Fig. 1 Mold and spacer for preparing porcelain specimens

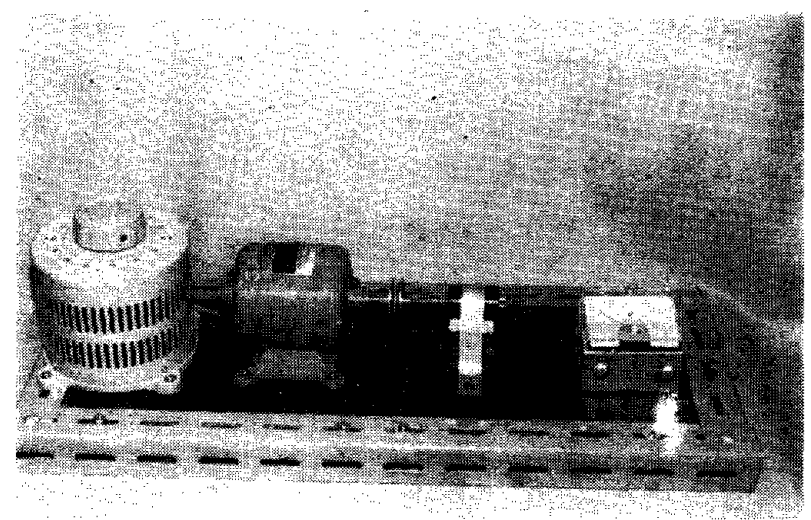

Fig. 2 Experimental condenser

$\mathrm{mm}$ の 3 通りにすることができる。

2) コンデンサー

試験片のコンデンスには，Fig. 2 に示すようなコン

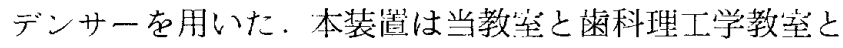
の其同で試作したもので，振動法によってコンデンスす るタイブである。Fig.2 の左側から，スライダック， モーター，ブーリー，タコメータ，電厌計である。 ス イダックによって電在を変え，モーターひいてはフーリ 一の问転数を変えることができる。試験片作製用テフロ ン型を固定しているアルミ板をブーリーにかるく接触さ せ，そのときに得られる振動を利用してコンデンス在行 うが，プーリーの回転数の相違による振動状態の差筫は Fig. $3^{20}$ 亿示す通りである. 本央験に使用したブーリ 一の回転数は $500,1000,2000,3000 \mathrm{r} \cdot \mathrm{p} \cdot \mathrm{m} \cdot$.の 4 種類 でそれを C500，C1000，C2000，C3000としてあらわ し,コンデンスの条件とした.

3；生型試験片の作製は，烝留水で混和した陶材沙 $\mathrm{W} / \mathrm{P}=0.4\rangle$ 内の気泡を，せっこうバィブレーターを 用いて可及的に排除し，テフロン型の上面まで填人し た。填入後, 試作コンデンサーを用いてコンデンスを行
C 500

$\mathrm{C} 1000$

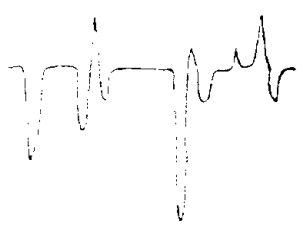

C 3000

Fig. 3 Typical vibration pattern for each condition of condensation.

った、コンデンスは，アルミ板をモーターのブーリーに 軽く接触させて振動を伝達することにより行った。水分 が浮いてくる度にガーゼで吸水するという操作をくり返 し，水分が浮いてこなくなるまで続けた。この操作は振 動開始から 1 分以内に完了するようにつとめた。さらに

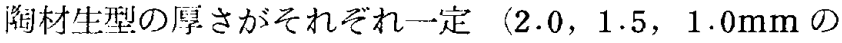
3 通り）になるように上方の余剰部を安全カミソリで削 除し，ただちにテフロン型から取り出して生型試験片と した。

垳材粉末と蒸留水とのなじみが比較的悪いため，コン デンスが不十分になることが予想される。そこで, 混和 淮として街材粉末となじみのよいアルコールを使用した 場合についても実験を行った。

4 試験片の燃成

的述した方法で作製した皁材生型試験片を $\mathrm{G}-\mathrm{C}$ Pyromat porcelain furnace を使用して，4 分間炉 乾燥, 3 分閏炉内乾燥した後, Table 1 に示す焼成 スケジュールにしたがって，大気焼成と真空焼成とを行 った。焼成はFig. 4 に亦すように, $650^{\circ} \mathrm{C}$ から $900^{\circ} \mathrm{C}$ までの㑭温速度を約 $22^{\circ} \mathrm{C} / \mathrm{min}$ に保つようにプログラム 制御して行った。焼成後，ただちに試験片を炉外にとり 


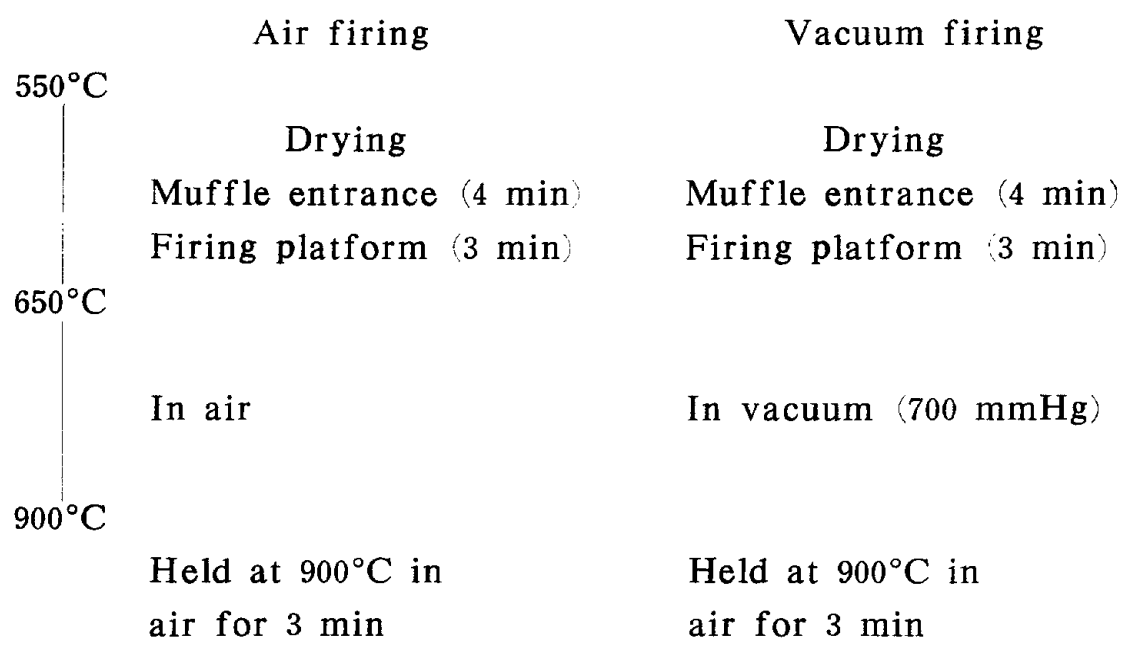

Table 1 Firing Schedule

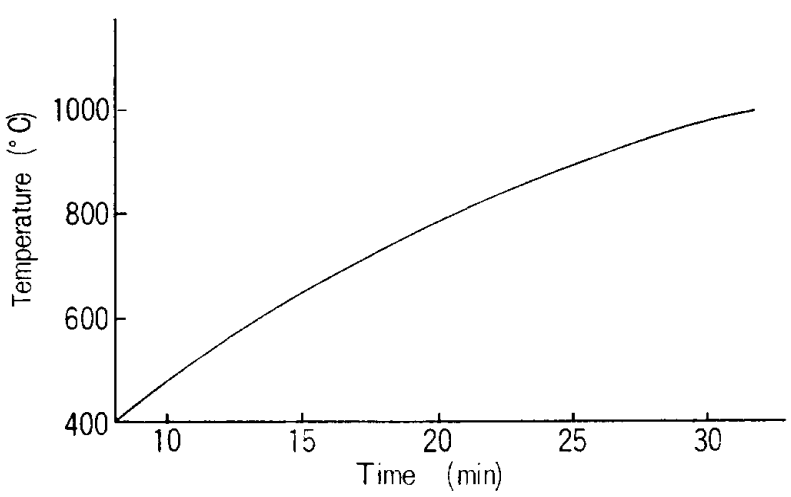

Fig. 4 Temperature versus time curve in porcelain furnace.

出し大気中で徐冷した。試験片は各実験条件につき 6 㑑 ずつ同時に焼成した。

実 験 装 置

\section{1. 乾燥器}

コンデンスした試験片生型の乾燥は Fig. 5 に示すよ うな減圧乾燥器を使用して行った。

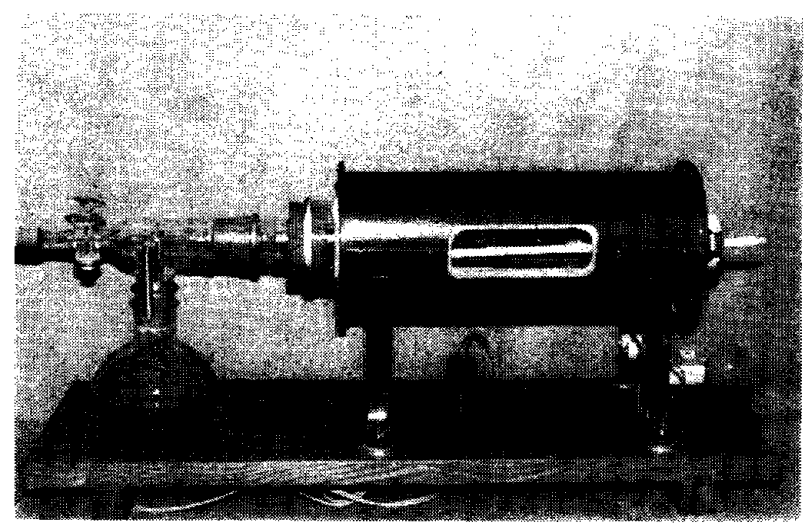

Fig. 5 Drying muffle
2. ベックマン比重計

衏材粉末の体積は東芝ベックマン社製のベックマン空 気比較式比重計 930型を使用して測定した。陶材粉末の 密度は，掏材粉末の体積と質量とを測定し，次の式を用 いて決定することができる。すなわち，

$$
\begin{array}{ll}
\mathrm{d}=\frac{\mathrm{m}}{\mathrm{v}} & \mathrm{d}: \text { 密度 } \\
& \mathrm{m}: \text { 陚材粉末の質量 } \\
& \mathrm{v}: \text { 陶材粉末の体積 }
\end{array}
$$

である・

3. 連通管

焼成後の試験片の体積は Fig.6 に示すような連通管 装置を直示天科にセットして測定した。

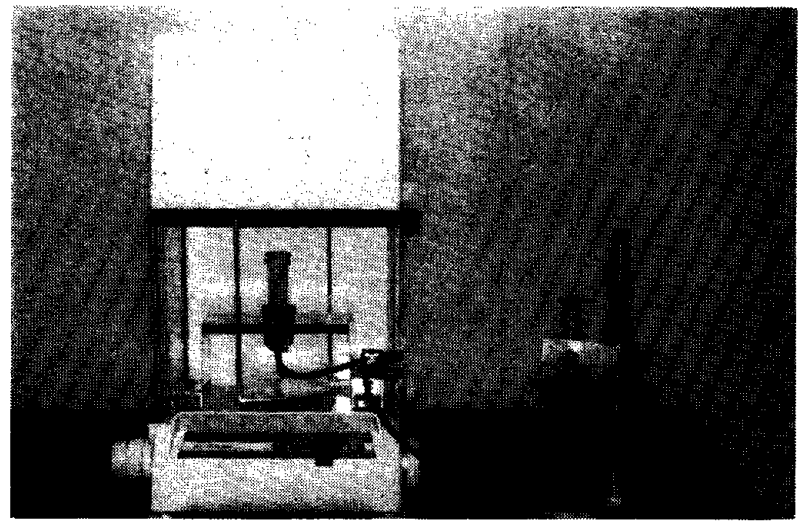

Fig. 6 Apparatus for measurement of apparent density (Essentially consists of modified chemical balance and communicating vessel.

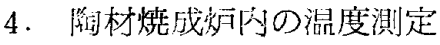

炉内の温度測定にはクロメル・アルメル熱電刘を用 い，指示温度計とペンレコーダー（Vp-6541 A，松下 
通信工業社製 でそれぞれを読みとることができるよう にした。

5. 造査型電子顕微鏡

实験に使用した電子顕微鏡は日本電子社製走查型電子 顕微镜 JEOL JSM 25 以下走查型電顕之略す であ 万。
奏験方法は以下のとおりである。

1 ) 要母 $\mathrm{A}$ とBの組み合わせについて

試験片の厚さを $1.0,1.5,2.0 \mathrm{~mm}$ とし，コンデンス の条俳をそれぞれ C500，C1000，C2000，C3000にした 場合の12種類の条件で武験片を作製した。コンデンス直 後の各試験片の void space $(\%)$ ，および焼成時の条 試験片の体収縮登上焼成後の内部ポロシティーとを測定

Table 2 Factors and Levels

\begin{tabular}{|c|c|c|c|c|}
\hline Factors $\quad$ Levels & 1 & 2 & 3 & 4 \\
\hline A. Thickness of specimen & $1.0 \mathrm{~mm}$ & $1.5 \mathrm{~mm}$ & $2.0 \mathrm{~mm}$ & - \\
\hline B. Condition of condensation & $\mathrm{C} 500$ & $\mathrm{C} 1000$ & $\mathrm{C} 2000$ & $\mathrm{C} 3000$ \\
\hline C. Firing atmosphere & air & vacuum & 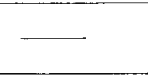 & - \\
\hline D. Mixing medium & alcohol & distilled water & - & - \\
\hline E. Firing temperature & $850^{\circ} \mathrm{C}$ & $900^{\circ} \mathrm{C}$ & $950^{\circ} \mathrm{C}$ & $980^{\circ} \mathrm{C}$ \\
\hline $\mathrm{F}$. Holding period at $900^{\circ} \mathrm{C}$ & $1 \mathrm{~min}$ & $3 \mathrm{~min}$ & $5 \mathrm{~min}$ & $7 \mathrm{~min}$ \\
\hline
\end{tabular}

\section{実 験 方 法}

\section{1. 岀験条件}

本捧験では，試験片の厭さ，コンデンス条件，烧成雾 用気，陶材混和液の種類，焼成温度，繫留時間などが陶 材の収縮抢よびポロシティーにいかなる影響を与えるか を検討した。

実験でとりあげる要因と水準は Table 2 に示した。 要因はA，B，C，D，E，Fの6つであり，それぞれ について通常の菌科臨床で行われている範囲内の 2 ない し 4 水準を設定した，各要因之水準を取り，次のような 組み合わせで要因配置を行い，くり返し6回の実験を試 みた。すなわち，

1) 要因 $\mathrm{A}$ （厚み）と要因 $\mathrm{B}$ (コンデンス条件)の組 み合わせ

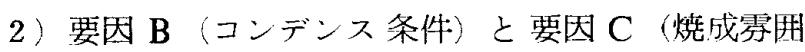
気）の組み合わせ

3) 要因D (混和液)と要因 B 〔コンデンス条件 の 組み合わせ

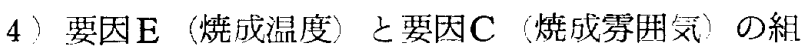
み合わせ

5 ) 要因 $F$ (熬留時間) と要因C (焼成䨌囲気) の紬 み合わせ

とした。

2. 奏験方法
した、試験片の焼成は大気焼成法で行った。

2) 要因 $\mathrm{B}$ とCの組み合わせについて

試験片の愿さを $1.5 \mathrm{~mm}$ 一定としたものを使用し，コ ンデンスを C500，C3000，としたものをそれぞれ 12個 ずつ作製し，そのそれぞれの12個のうち 6 個を大気焼成 し, 残りの 6 個を真空焼成した。焼成した試験片の体収 縮率と内部ポロシティーとを測定した。

3 ) 要因 $\mathrm{D}$ と Bの組み合わせについて

試験片の厚さを $1.5 \mathrm{~mm}$ 一定としたものを使用し，烝 留水とアルコールとをそれぞれ陶材の混和液とし, コン デンスの条件をそれぞれ C500,C3000 とした場合の 4

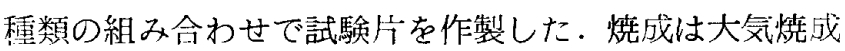
法で行った，焼成した試験片の体收縮率と内部ポロシテ ィーとを測定した。

4) 要因 $\mathrm{E}$ と $\mathrm{C}$ 組み合わせについて

コンデンスの条件を C 3000 一定として，1.5mm 厚さ の試験片を使用した。烧成温度を $850 ， 900 ， 950 ， 980$ ${ }^{\circ} \mathrm{C} の 4$ 種類とし，真空焼成と大気焼成之を行った。焼 成した試験片の体収縮率と内部ポロシティーとを測定し た。

5 ) 要因 $\mathrm{F}$ と $\mathrm{C}$ の組み合わせについて

コンデンスの条件を $\mathrm{C} 3000$ 一定として，1.5mm の厚 さの試験片を使用した。焼成方法は大気焼成法と真空焼 咸法の 2 種類で，まず $900^{\circ} \mathrm{C}$ まで昇温し，その後熬留時 閒在 $1 ， 3 ， 5 ， 7$ 分間の 4 種類とした。焼成時の試験 
片の体収縮率と焼成後の内部ポロシティーとを測定し た。

\section{3. 測定方法}

1) Void space (\%) の測定 ${ }^{21)}$

テフロン型からとり出した生型試験片についてはまず 見かけの体積を算出した。厚さについては 4 個所を計測 してその平均值を，また直径については 3 個所を計測し てその平均值をそれぞれ計測值とした。 また計測には読 取顕微鏡を用い， $1 / 100 \mathrm{~mm}$ の精度まで計測した．次に 各生型試験片は, $120^{\circ} \mathrm{C}$ で 5 時間, 減圧乾燥器を用いて 乾燥した．乾燥後重さを測定し，さらにベックマン比重 計で決定した陶材粉末の真の比重から試験片の真の体積 を求めた. 生型試験片の見かけの体積と真の体積からコ ンデンス直後の試験片の void space $(\%)$ を次の式を 用いて算出した. すなわち，

Void space $(\%)=\frac{\mathrm{Vc}-\mathrm{Vp}}{\mathrm{Vc}} \times 100$ ただし Vc：コンデンス直後の試験片の見かけの体積 $\mathrm{Vp}:$ コンデンス值後の試験片の真の体積 である.

2 ) ポロシティーの測定 22-26)

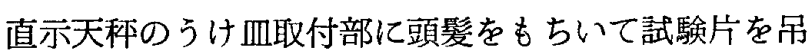
し連通管の一方の管中に置く。もう一方の管からメチル アルコールを入れ，その管を上下するととにより天科に セットされた試験片部分だけをメチルアルコール中に浸 漬できるようにした，浸漬前の重量( $\left.\mathbf{W}_{1}\right)$ と浸漬中の 重量 $\left(\mathrm{W}_{2}\right)$ を科量し，次の $\left.\mathrm{a}\right)$ 式から試験片の見かけ の此重を求めたのち，b）式を用いてポロシティーを算 出した、すなわち,

a) $\rho_{\mathrm{r}}=\frac{\mathrm{W}_{1}}{\mathrm{~W}_{1}-\mathrm{W}_{2}} \rho_{\text {。 }}$

b) porosity $(\%)=\frac{\rho-\rho \mathrm{a}}{\rho} \times 100$ である.

なお

$\mathrm{W}_{1}$ : 試駼片の浸漬前の重量

$\mathrm{W}_{2}$ : 試験片の浸漬中の重量

。 : メチルアルコールの比重

$\rho:$ 陶材粉末の真の比重

$\rho_{\mathrm{a}}:$ : 試験片の見かけの比重

である. 全ての実験は $19 \pm 1{ }^{\circ} \mathrm{C}$ の室温のもとで行った。

3 ) 焼成時の収縮率の測定

炡成後の試験片の見かけの比重と重さから体積を求 め, 焼成時の収縮率を次の式を用いて算出した。すなわ ち,

Volumetric shrinkage $(\%)=\frac{\mathrm{Vc}-\mathrm{Vh}}{\mathrm{Vc}} \times 100$
ただし Vc：コンデンス直後の生型試験片の見かけの体 積

$\mathrm{Vh}:$ 焼成後の試験片の見かけの体積 である。

以上 1) 〜 3) の各測定は, 同一試験片について 3 |凷 くりかえし行い，その平均值をその試験片の測定值とし た。これらの測定結果について分散分析を行い，危険率 $5 \%$ で有意差の検定を行った。

4) 走査型電顕による観察

走査型電顕による観察は焼成後の陶材の円形表面と, その面に対して垂直な方向に 2 分割したときの破面とに つて行った。

円形表面を観察する試験片については, 観察面に直接 goldによる ion sputter coating を行った. また， 破面を観察する試験片も，アルミナ(100番)を用いて 破面をあらかじ研磨し, 十分に洗浄し, 乾燥したもの に gold による ion sputter coating を行って使用し た。

気泡の分布状態は，走査電顕写真上で檢討した。

\section{実 酫 結 果}

1. Void space $(\%)$ の測定

コンデンスの条件と生型試験片の厚さを，それぞれ変 えた場合の void space（\%)の変化を調べた，その結 果については, Table 3, Fig.7亿示す.

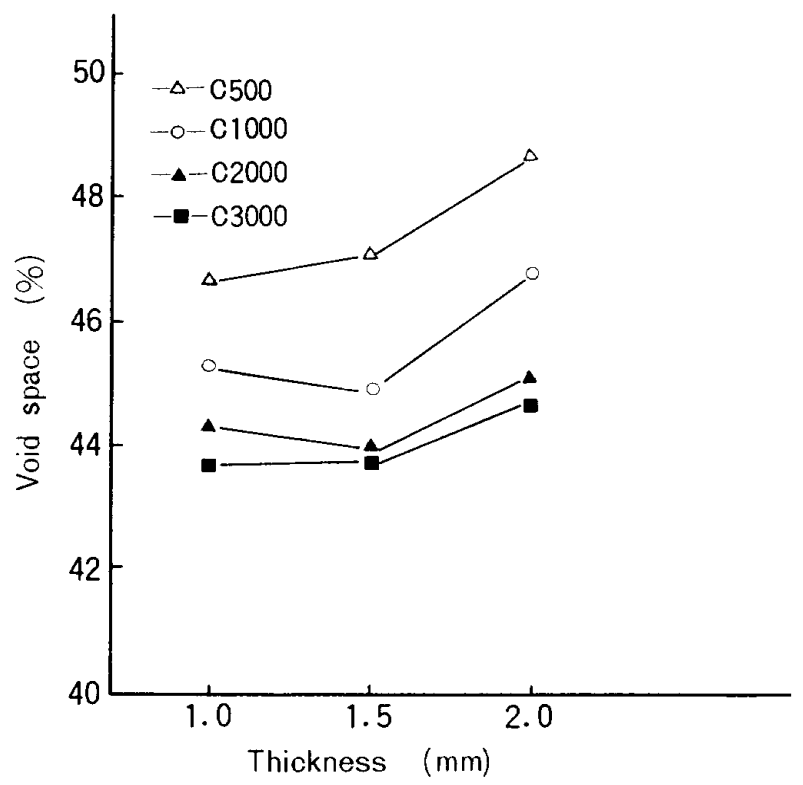

Fig. 7 Effect of thickness of specimen on void space of porcelain after condensation. 
Table 3 Effect of thickness of specimen on void space of porcelain after each condensation.

\begin{tabular}{|c|c|c|c|c|c|c|c|c|c|}
\hline thickness & & 1 & 2 & 3 & 4 & 5 & 6 & M & $S \cdot D$. \\
\hline \multirow{4}{*}{$1.0 \mathrm{~mm}$} & C500 & 46.87 & 45.80 & $47 \cdot 36$ & 46.25 & 46.58 & 47.60 & 46.74 & 0.68 \\
\hline & C 1000 & 44.06 & 45.52 & 44.24 & 45.87 & 46.18 & 46.03 & 45.32 & 0.93 \\
\hline & C 2000 & 44.39 & 44.74 & 43.26 & 44.23 & 45.66 & 43.54 & 44.30 & 0.86 \\
\hline & C 3000 & 44.22 & 45.52 & 42.17 & 43.79 & 43.42 & $43 \cdot 15$ & 43.71 & 1.12 \\
\hline \multirow{4}{*}{$1.5 \mathrm{~mm}$} & C500 & 45.75 & 48.35 & 47.03 & 47.76 & 46.74 & 48.25 & 47.15 & 0.99 \\
\hline & C 1000 & 44.51 & 44.73 & 44.53 & 44.85 & 45.75 & 45.24 & 44.94 & 0.48 \\
\hline & C2000 & 42.74 & 43.86 & 43.98 & 44.52 & 44.92 & $44 \cdot 42$ & 44.01 & 0.68 \\
\hline & C 3000 & 43.95 & 42.69 & 44.44 & 43.78 & 43.96 & 43.88 & 43.78 & 0.58 \\
\hline \multirow{4}{*}{$2.0 \mathrm{~mm}$} & C500 & 48.57 & 48.91 & 49.34 & 48.63 & 48.07 & 48.95 & 48.75 & 0.43 \\
\hline & C 1000 & 46.69 & 48.51 & 46.11 & 46.22 & 47.51 & 46.48 & 46.92 & 0.92 \\
\hline & $\mathrm{C} 2000$ & 46.19 & 45.53 & 45.24 & 44.02 & 45.02 & $45 \cdot 18$ & 45.20 & 0.71 \\
\hline & C 3000 & 45.10 & 45.78 & 45.32 & 43.36 & 44.14 & 44.55 & 44.71 & 0.88 \\
\hline
\end{tabular}

分散分析の結果から明らかなように，試験片の厚さを $1.0,1.5,2.0 \mathrm{~mm}$ としたいずれの場合においても，コ ンデンス直後の void space $(\%)$ には C500, C1000, C2000の間に有意差が梁められた。しかし，C2000のも のとC3000のものとの間では有意差が認められなかっ た. Fig. 7 から明らかなように，いずれのコンデンス 条件においても，void space $(\%)$ は厚さが1.0mm $1.5 \mathrm{~mm}$ のものでは変化がみられなかったが，C2000 と C3000のものを除いて $1.5 \mathrm{~mm}$ と $2.0 \mathrm{~mm}$ ののでは, 2.0 $\mathrm{mm}$ の方が大きくなる傾向を示した。

2. 焼成時の収維率の湘定
1)試験片の厚さとコンデンス

試験片の厚さとコンデンスの条件を変えた場合の焼成 時の体収縮率の変動について検討を行った．変動の様相 を Table 4 と Fig. 8 亿示す.試験片の厚さが $1.5 \mathrm{~mm}$ と $2.0 \mathrm{~mm}$ のものでは，いずれも焼成時の体收縮率につ いて，コンデンス条件 C500，C1000，C2000 の間で は，有意差が認められたが，C2000 と C3000 との間で は有意差が認められなかった。試験片の厚さが $1.0 \mathrm{~mm}$ のものでは，C500 と C1000の開では，体収縮率に有䁇 差がみられたが，C1000から C3000までのものでは有意 美がみられなかった。一方，試験片の厚さ開では，いず

Table 4 Effect of thickness of specimen on firing shrinkage of porcelain for each condition of condensation.

\begin{tabular}{|c|c|c|c|c|c|c|c|c|c|}
\hline thickness & & 1 & 2 & 3 & 4 & 5 & 6 & $\mathrm{M}$ & S.D. \\
\hline \multirow{4}{*}{$1.0 \mathrm{~mm}$} & C 500 & 43.23 & 42.65 & 43.76 & 43.00 & 43.38 & 42.82 & 43.14 & 0.40 \\
\hline & C 1000 & 40.91 & $42 \cdot 20$ & 40.92 & 42.64 & 42.54 & 42.29 & 41.92 & 0.79 \\
\hline & C 2000 & 40.67 & 41.51 & 39.65 & 41.13 & 42.51 & 39.60 & 40.85 & 1.10 \\
\hline & C 3000 & 41.06 & 41.35 & 38.89 & 40.35 & 39.65 & 39.92 & 40.20 & 0.91 \\
\hline \multirow{4}{*}{$1.5 \mathrm{~mm}$} & C 500 & 42.04 & 43.55 & 43.42 & 42.87 & 42.85 & 44.68 & 43.24 & 0.89 \\
\hline & C 1000 & 40.70 & 41.01 & 40.79 & 41.12 & 42.36 & 41.56 & 41.26 & 0.62 \\
\hline & C 2000 & 39.24 & 40.15 & 40.38 & 40.48 & 41.19 & 40.50 & 40.32 & 0.63 \\
\hline & C 3000 & 40.59 & 39.13 & 40.93 & 40.01 & 40.49 & 39.76 & 40.15 & 0.65 \\
\hline \multirow{4}{*}{$2.0 \mathrm{~mm}$} & $\mathrm{C} 500$ & 46.41 & 45.64 & 46.00 & 45.82 & 45.33 & 45.85 & 45.84 & 0.36 \\
\hline & $\mathrm{C} 1000$ & 44.92 & 43.12 & 43.45 & 44.38 & 43.18 & 44.89 & 43.99 & 0.84 \\
\hline & $\mathrm{C} 2000$ & 42.60 & 42.05 & 41.32 & $41 \cdot 27$ & 41.44 & 41.77 & 41.74 & 0.51 \\
\hline & C 3000 & 41.44 & 42.38 & 41.89 & 39.89 & 39.24 & 40.89 & 40.95 & 1.20 \\
\hline
\end{tabular}




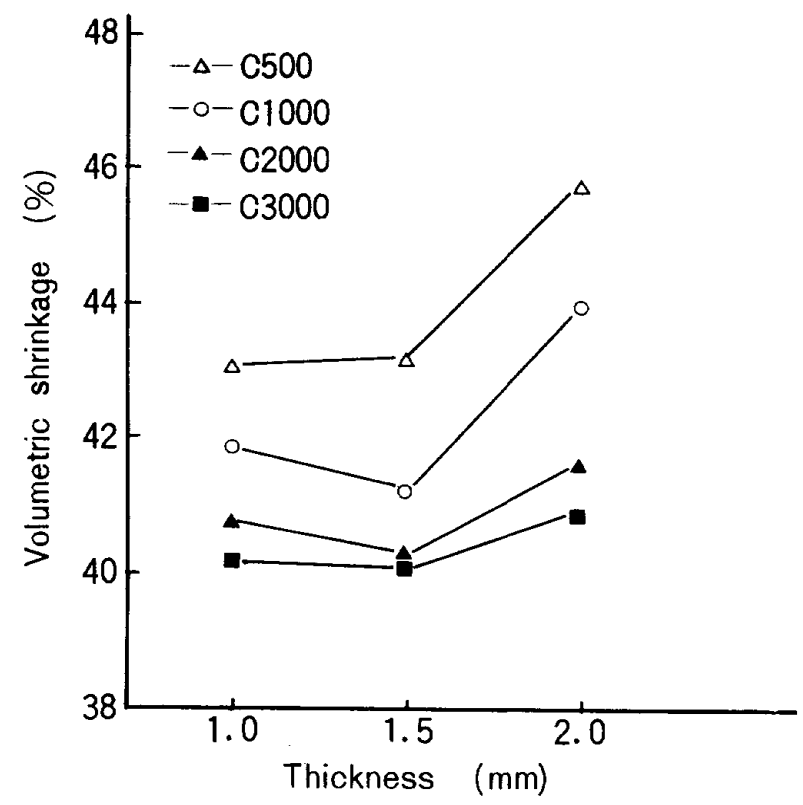

Fig. 8 Effect of thickness of specimen on firing shrinkage of porcelain for each condition of condensation.

れのコンデンス条件においても，収縮率は厚さが 1.0 $\mathrm{mm}$ のもの $1.5 \mathrm{~mm}$ のものとの間には有意差が認めら れなかったが，C3000のものを除いて 1.5mmのものと $2.0 \mathrm{~mm}$ のものとの間には有意差が認められた。これら の結果から，体収縮率はコンデンスが十分なものよりコ ンデンスが不十分なものの方が大きく，しかもその程度 は厚さが1.0〜1.5mmの時より1.5〜2.0mm の時の方が 著しいことが判明した。

Table 5 Effect of firing atmosphere on firing shrinkage of porcelain for different condition of condensation.

$(\%)$

\begin{tabular}{r|r|r|r|r}
\hline \hline & \multicolumn{2}{|c|}{ air firing } & \multicolumn{2}{c}{ vacuum firing } \\
\cline { 2 - 5 } & C500 & C 3000 & C500 & C 3000 \\
\hline 1 & 43.21 & 41.23 & 42.85 & 42.16 \\
2 & 42.04 & 41.37 & 44.42 & 41.71 \\
3 & 43.25 & 40.78 & 44.32 & 41.75 \\
4 & 41.92 & 41.71 & 42.09 & 42.08 \\
5 & 42.76 & 41.04 & 43.51 & 43.44 \\
6 & 42.29 & 40.07 & 44.47 & 40.14 \\
\hline M & 42.58 & 41.07 & 43.61 & 41.88 \\
\hline S .D. & 0.58 & 0.50 & 0.98 & 1.06 \\
\hline
\end{tabular}

2) コンデンスと焼成雾囲気

コンデンス条件と焼成雾囲気（真空，大気）を変えた 場合の㸁成時の試験片の体収縮率の変動を検討した、変 動の様相を Table 5 と Fig. 9 亿示す. 分散分析の結 果から明らかなように，コンデンス条件がC500，C3000 のいずれの場合にも，大気焼成したものと真空焼成した ものとの間で焼成時の試験片の収縮率に有意差は認めら れなかった。

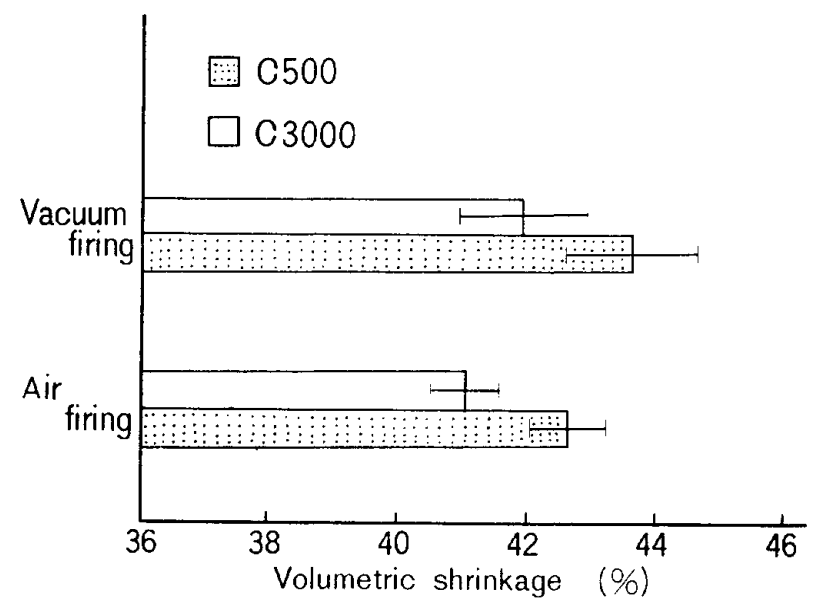

Fig. 9 Effect of firing atmosphere on firing shrinkage of porcelain for different condition of condensation.

3 ）混和液とコンデンス

陶材混和液とコンデンス条件を変えた場合の烧成時の 試験片収縮率を Table 6 と Fig.10 亿示した。これに よると，コンデンス条件が C500，C3000 のいずれの場

Table 6 Effect of kind of mixing medium on firing shrinkage of porcelain for different condition of condensation.

(\%)

\begin{tabular}{r|c|c|c|c}
\hline & \multicolumn{2}{|c}{ distilled water } & \multicolumn{2}{c}{ alcohol } \\
\hline & C500 & C3000 & C500 & C 3000 \\
\hline 1 & 43.76 & 41.67 & 42.98 & 41.85 \\
2 & 43.31 & 42.51 & 44.11 & 41.59 \\
3 & 44.15 & 40.40 & 44.06 & 40.80 \\
4 & 43.98 & 41.92 & 43.41 & 41.19 \\
5 & 43.93 & 42.17 & 43.37 & 40.70 \\
6 & 43.35 & 40.78 & 44.28 & 40.26 \\
\hline M & 43.75 & 41.58 & 43.70 & 41.07 \\
\hline S .D. & 0.35 & 0.82 & 0.52 & 0.59 \\
\hline
\end{tabular}




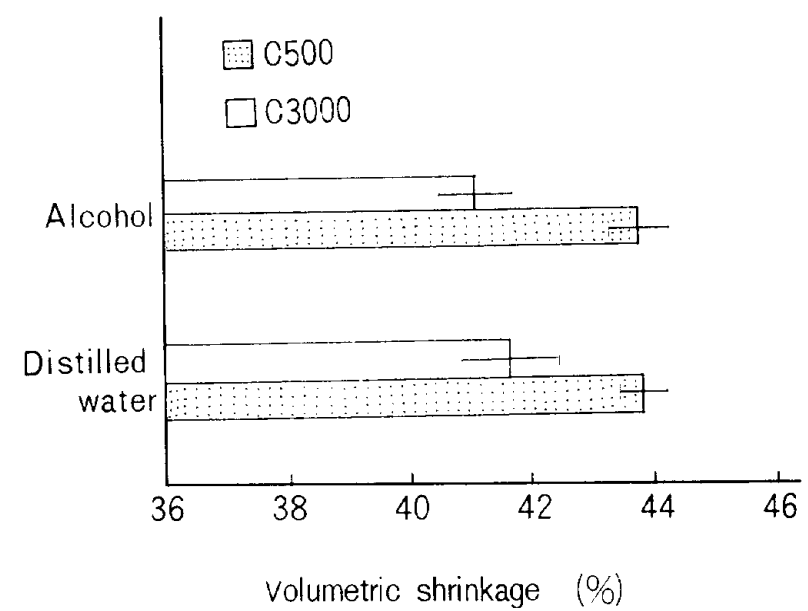

Fig. 10 Effect of kind of mixing medium on firing shrinkage of porcelain for different condition of condensation.

合についても，蒸留水を混和液としたものとアルコール を混和液としたものとの間に有意差は認められなかっ た．すなわち，混和淮が蒸留水であるかアルコールであ るかの相違は焼成時の試験片の収縮率に何らはっきりと した相違を与えないことが判明した。

\section{4) 焼成温度と焼成雲囲気}

焼成温度と焼成雲囲気をそれぞれ変えた場合の焼成時 の試験片の体収縮を Table 7 と Fig.11 に示した。こ れによると，焼成時の試験片の収縮率は，真空焼成，大 気焼成のいずれの場合にも，最終燒成温度が高くなるに したがって増大する傾向がある。しかし大気焼成の場
用気の相違による収縮率の差異は， $850 ， 900^{\circ} \mathrm{C}$ ではみ られなかったが， $950 ， 980^{\circ} \mathrm{C}$ ではいずれの温度におい ても真空焼成したものの方が大気焼成したものよりも大 きな体収縮率を示した。

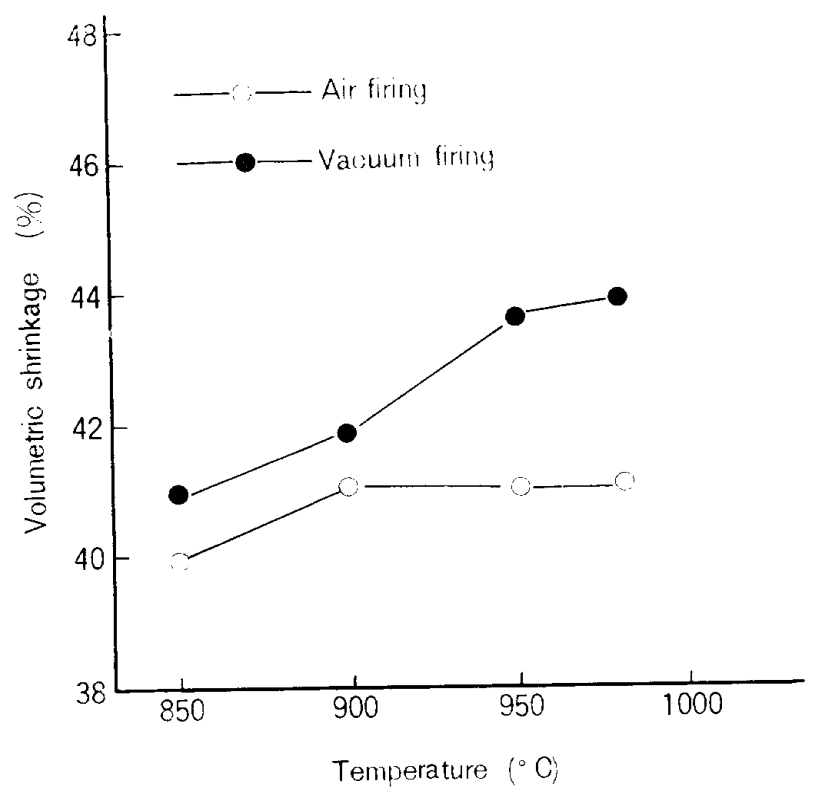

Fig. 11 Effect of firing temperature on firing shrinkage of porcelain for different firing atmosphere.

5 ) 紫留時問と焼成雾囲気

$900^{\circ} \mathrm{C}$ 亿熬留する時間と焼成雾团気とをそれぞれ変え た場合，焼成時の試験片の収縮率がぞのように変動する

Table 7 Effect of firing temperature on firing shrinkage of porcelain for different firing atmosphere.

$(\%)$

\begin{tabular}{c|rrrr|rrrr}
\hline \hline & \multicolumn{5}{|c}{ air } & \multicolumn{1}{c}{ firing } & \multicolumn{3}{|c}{ vacuum } & firing \\
\cline { 2 - 9 } & $850{ }^{\circ} \mathrm{C}$ & $900^{\circ} \mathrm{C}$ & $950{ }^{\circ} \mathrm{C}$ & $980^{\circ} \mathrm{C}$ & $850{ }^{\circ} \mathrm{C}$ & $900^{\circ} \mathrm{C}$ & $950{ }^{\circ} \mathrm{C}$ & $980{ }^{\circ} \mathrm{C}$ \\
\hline 1 & 40.41 & 41.37 & 40.00 & 41.00 & 40.63 & 41.75 & 42.29 & 44.00 \\
2 & 40.40 & 41.23 & 41.24 & 40.18 & 41.09 & 43.44 & 44.16 & 43.63 \\
3 & 39.94 & 40.78 & 40.95 & 42.23 & 40.97 & 42.16 & 43.79 & 44.14 \\
4 & 38.28 & 41.71 & 40.25 & 40.85 & 39.98 & 40.14 & 43.42 & 43.71 \\
5 & 40.50 & 41.04 & 43.13 & 40.90 & 41.81 & 41.71 & 44.22 & 43.82 \\
6 & 40.08 & 40.27 & 40.43 & 41.18 & 41.00 & 42.08 & 44.10 & 43.82 \\
\hline M & 39.94 & 41.07 & 41.00 & 41.06 & 40.91 & 41.88 & 43.66 & 43.85 \\
\hline S.D. & 0.84 & 0.50 & 1.14 & 0.68 & 0.60 & 1.06 & 0.74 & 0.19 \\
\hline
\end{tabular}

合，焼成温度が $850^{\circ} \mathrm{C}$ ののと $900^{\circ} \mathrm{C}$ のもとの間には

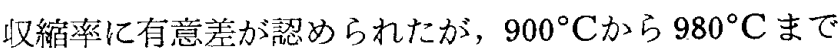
のものの間には有意差が認められなかった。一方焼成雾
かについて検討した。変動の様相を Table 8 と Fig.12 に示す．各時間繫留した試験片の收縮率には，烍成雾囲 気の違いによる有意差は認められなかった。Fig.12で 
Table 8 Effect of holding period on firing shrinkage of porcelain for different firing atmosphere.

(\%)

\begin{tabular}{|c|c|c|c|c|c|c|c|c|}
\hline & \multicolumn{2}{|r|}{ air } & \multicolumn{2}{|l|}{ firing } & \multicolumn{2}{|r|}{ vacuum } & \multicolumn{2}{|l|}{ firing } \\
\hline & $1 \mathrm{~min}$ & $3 \mathrm{~min}$ & $5 \mathrm{~min}$ & $7 \mathrm{~min}$ & $1 \mathrm{~min}$ & $3 \min$ & $5 \min$ & $7 \mathrm{~min}$ \\
\hline 1 & 41.09 & 41.37 & 42.43 & 42.60 & 42.65 & 41.75 & 43.02 & 42.37 \\
\hline 2 & 41.14 & $41 \cdot 23$ & 42.46 & 42.31 & 41.15 & 43.44 & 43.28 & 43.09 \\
\hline 3 & 41.54 & 40.78 & 42.87 & 42.51 & 41.27 & 42.16 & 42.52 & 43.39 \\
\hline 4 & 41.70 & 41.71 & 42.66 & 42.59 & 41.47 & 40.14 & 42.25 & 43.29 \\
\hline 5 & 40.42 & 41.04 & 43.82 & 42.89 & 42.03 & 41.71 & 43.26 & 42.71 \\
\hline 6 & 41.40 & 40.27 & 42.10 & 43.12 & 41.20 & 42.08 & 42.76 & 43.90 \\
\hline $\mathbf{M}$ & 41.22 & 41.07 & 42.72 & 42.67 & 41.63 & 41.88 & 42.85 & 43.13 \\
\hline $\mathrm{S} \cdot \mathrm{D}$. & 0.45 & 0.50 & 0.60 & 0.29 & 0.60 & 1.06 & 0.41 & 0.54 \\
\hline
\end{tabular}

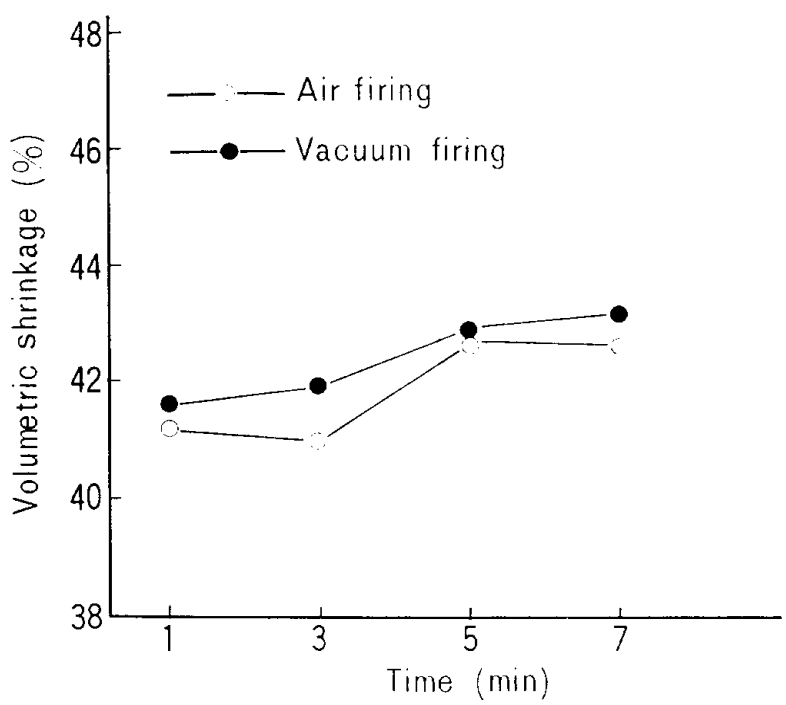

Fig. 12 Effect of holding period on firing shrinkage of porcelain for different firing atmosphere.

判るように，真空焼成した試験片と大気烧成した試験片 のいずれにおいても，䔝留時間の延長により収縮率にわ ずかな增大が起てる．分散分析を行った結果，大気焼成 した場合では，熬留時間を 5 分， 7 分としたものの収維 率の間には有意差は認められなかったが，てれらのもの と 1 分， 3 分熬留したものの閒では有意差が認められ た。一方, 真空焼成した場合では, 熬留時間を 1 分と 3 分, 3 分と 5 分, 5 分と 7 分としたものの間には有意差 が認められなかったが， 1 分熬留したものと 7 分繁留し たものとの間には有意差が認められた。

3. ポロシティーの測定

1) 試験片の厚さとコンデンス

試験片の厚さおよびコンデンスの条件を変えた場合,
焼成後の試験片のポロシティーがどのように変動するか について検討を行った．変動の様相を Table 9 と Fig. 13に示す。乙れによると, それぞれの厚さの試験片にお いてはコンデンス条件の相違による焼成後の試験片のポ ロシティーの差異はみられなかった。しかし, 試験片の 厭さが薄い場合 $(1.0 \mathrm{~mm})$ と厚さが愿い場合 $(2.0 \mathrm{~mm})$ との閂には, 後者の場合, ポロシティーがわずかに増大 する傾向がみられた。

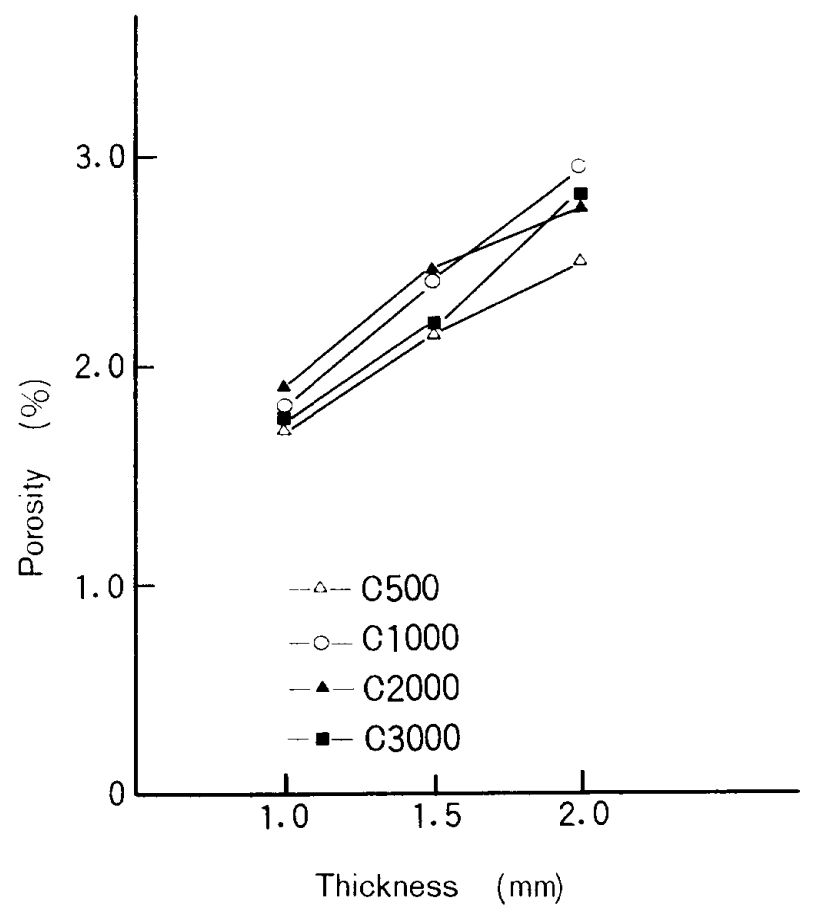

Fig. 13 Effect of thickness of specimen on internal porosity of fired porcelain for different condition of condensation. 
Table 9 Effect of thickness of specimen on internal porosity of fired porcelain for each condition of condensation.

\begin{tabular}{|c|c|c|c|c|c|c|c|c|c|}
\hline thickness & & 1 & 2 & 3 & 4 & 5 & 6 & $\mathrm{M}$ & S.D. \\
\hline \multirow{4}{*}{$1.0 \mathrm{~mm}$} & C500 & 2.263 & 1.276 & 2.387 & 1.770 & 1.193 & 1.276 & 1.694 & 0.531 \\
\hline & $\mathrm{C} 1000$ & 1.358 & 1.646 & 1.481 & 1.646 & 2.675 & 2.675 & 1.761 & 0.525 \\
\hline & C 2000 & 2.675 & 1.399 & 2.016 & 1.193 & 1.276 & 2.922 & 1.913 & 0.748 \\
\hline & C 3000 & 1.358 & 1.811 & 1.728 & 1.852 & 2.387 & 1.399 & 1.756 & 0.373 \\
\hline \multirow{4}{*}{$1.5 \mathrm{~mm}$} & $\mathrm{C} 500$ & 2.346 & 2.016 & 2.305 & 2.510 & 2.675 & 1.181 & 2.172 & 0.533 \\
\hline & $\mathrm{C} 1000$ & 2.469 & 2.346 & 2.798 & 2.798 & 1.811 & 2.305 & 2.421 & 0.368 \\
\hline & C2000 & 1.893 & 2.634 & 2.510 & 2.469 & 2.469 & 2.593 & 2.428 & 0.271 \\
\hline & C 3000 & 1.728 & 2.058 & 2.058 & 2.387 & 1.934 & 2.963 & 2.188 & 0.436 \\
\hline \multirow{4}{*}{$2.0 \mathrm{~mm}$} & C 500 & 2.551 & 2.922 & 2.099 & 2.757 & 2.058 & 2.675 & 2.510 & 0.356 \\
\hline & $\mathrm{C} 1000$ & 2.881 & 3.663 & 2.387 & 2.922 & 3.045 & 2.757 & 2.943 & 0.419 \\
\hline & C 2000 & 2.675 & 2.798 & 2.593 & 2.881 & 2.963 & 2.675 & 2.764 & 0.141 \\
\hline & C 3000 & 2.798 & 2.675 & 2.634 & 2.675 & 2.881 & 3.004 & 2.778 & 0.144 \\
\hline
\end{tabular}

2) コンデンスと焼成雾囲気

コンデンス条件と焼成雾囲気（真空，大気）を変えた 場合，焼成後の試験片のポロシティーがどのように変動 するか沉つて検討を行った. 変動の様相を Table 10 と Fig.14 に示す。これらの結果から明らかなようにコ ンデンスの条件が C500とC3000のいずれの場合も焼成 後のポロシティーに大気焼成したものと真空焼成したも のとの間で有意差が珰められなかった。

Table 10 Effect of firing atmosphere on internal porosity of fired porcelain for different condition of condensation.

$(\%)$

\begin{tabular}{c|c|c|c|c}
\hline \multirow{2}{*}{} & \multicolumn{2}{|c|}{ air firing } & \multicolumn{2}{c}{ vacuum firing } \\
\cline { 2 - 5 } \cline { 5 - 5 } & C500 & C 3000 & C500 & C 3000 \\
\hline 1 & 2.575 & 2.634 & 2.551 & 2.346 \\
2 & 1.770 & 1.687 & 2.099 & 2.263 \\
3 & 2.058 & 1.728 & 2.469 & 2.387 \\
4 & 2.099 & 2.181 & 1.975 & 1.770 \\
5 & 2.469 & 1.811 & 1.893 & 1.934 \\
6 & 1.646 & 2.551 & 2.305 & 2.510 \\
\hline M & 2.133 & 2.099 & 2.215 & 2.202 \\
\hline S .D. & 0.419 & 0.421 & 0.268 & 0.287 \\
\hline
\end{tabular}

3）混和液とコンデンス

コンデンス条件と陶材混和腹を変えた場合，焼成後の 試験片のポロシティーがどのように変動するかを検討し

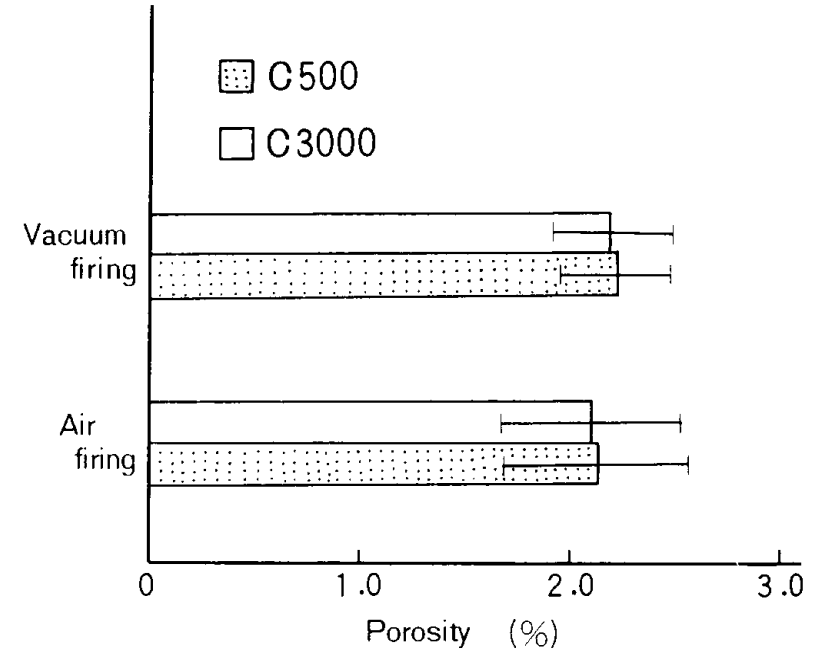

Fig. 14 Effect of firing atmosphere on internal porosity of fired porcelain for different condition of condensation.

た.変動つ様相を Table 11 と Fig.15に示す.とれに よると, 混和夜として蒝留水, アルコールをそれぞれ用 いた場合の焼成後の試験片のポロシティーは収䌬率と同 様に，C500と C3000のいずれの場合においても差がみ られなかった。

\section{4) 焼成温度と焼成弅囲気}

焼成温度と焼成㞣囲気を変えた場合, 焼成後の試験片 のポロシティーがどのように変動するかについて検討し た. 変動の样相を Table 12 と Fig.16亿示す.これに よると，燒成雲囲気の相違によるポロシティ一の差異 は，焼成温度 $850^{\circ} \mathrm{C}$ と $900^{\circ} \mathrm{C}$ ではあまりみられなかった 
Table 11 Effect of kind of mixing medium on interna1 porosity of fired porcelain for different condition of condensation.

$(\%)$

\begin{tabular}{c|c|c|c|c}
\hline \multirow{2}{*}{} & \multicolumn{2}{|c|}{ distilled water } & \multicolumn{2}{c}{ alcohol } \\
\cline { 2 - 5 } & C500 & C 3000 & C500 & C3000 \\
\hline 1 & 2.881 & 3.086 & 2.305 & 1.770 \\
2 & 1.852 & 1.811 & 1.975 & 2.222 \\
3 & 3.004 & 2.428 & 1.852 & 2.140 \\
4 & 2.387 & 1.605 & 2.469 & 2.263 \\
5 & 1.811 & 1.687 & 2.634 & 2.798 \\
6 & 1.893 & 3.333 & 1.770 & 1.646 \\
\hline M & 2.305 & 2.325 & 2.168 & 2.140 \\
\hline S D & 0.538 & 0.748 & 0.353 & 0.409 \\
\hline
\end{tabular}

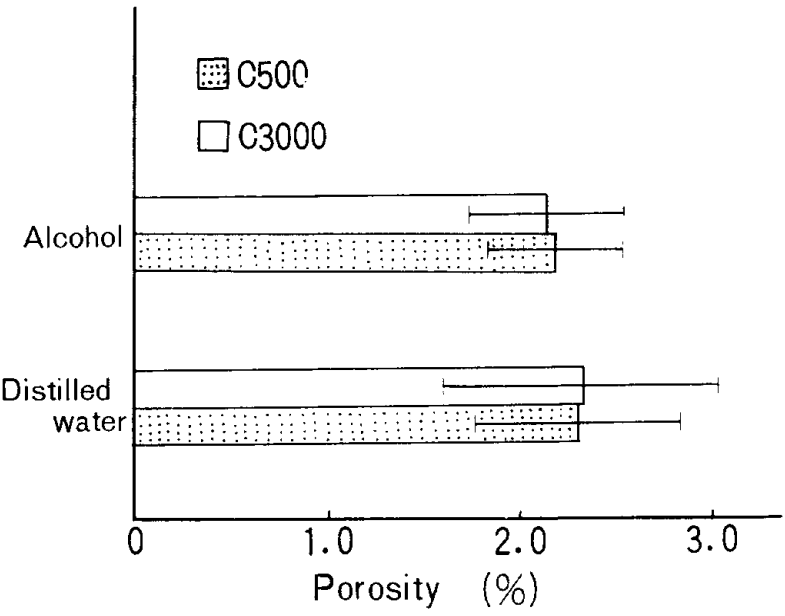

Fig. 15 Effect of kind of mixing medium on internal porosity of fired porcelain for different condition of condensation.

Table 12 Effect of firing temperature on internal porosity of fired porcelain for firing atmosphere.

$(\%)$

\begin{tabular}{|c|c|c|c|c|c|c|c|c|}
\hline & & air & firing & & & vacuum & firing & \\
\hline & $850^{\circ} \mathrm{C}$ & $900^{\circ} \mathrm{C}$ & $950^{\circ} \mathrm{C}$ & $980^{\circ} \mathrm{C}$ & $850^{\circ} \mathrm{C}$ & $900^{\circ} \mathrm{C}$ & $950^{\circ} \mathrm{C}$ & $980^{\circ} \mathrm{C}$ \\
\hline 1 & 3.909 & 2.634 & 2.016 & 2.346 & 3.951 & 1.440 & 1.092 & 0.658 \\
\hline 2 & 4.774 & 2.410 & 0.700 & 1.317 & 3.457 & 1.605 & 0.782 & 0.370 \\
\hline 3 & 4.691 & 1.605 & 2.099 & 2.716 & 3.786 & 2.387 & 0.247 & 0.947 \\
\hline 4 & 3.868 & 1.317 & 1.646 & 1.811 & 4.733 & 2.181 & 0.905 & 0.947 \\
\hline 5 & 3.416 & 2.222 & 0.617 & 1.687 & 3.498 & 2.428 & 0.494 & 1.687 \\
\hline 6 & 3.868 & 2.510 & 1.934 & 1.687 & 3.786 & 2.346 & 0.782 & 1.317 \\
\hline $\mathrm{M}$ & 4.088 & 2.116 & 1.502 & 1.927 & 3.869 & 2.065 & 0.707 & 0.988 \\
\hline S.D. & 0.532 & 0.533 & 0.671 & 0.510 & 0.464 & 0.431 & 0.287 & 0.467 \\
\hline
\end{tabular}

が， $950^{\circ} \mathrm{C}$ と $980^{\circ} \mathrm{C}$ では真空焼成したものよりも，大気 焼成したものの方が高い値を示した。これに対して，大 気焼成した場合のポロシティーは焼成温度か $850^{\circ} \mathrm{C}$ の場 合 $4.1 \%, 900^{\circ} \mathrm{C}$ の場合 $2.1 \%, 950^{\circ} \mathrm{C}$ の場合 $1.5 \%$ とな り，哑成温度が高くなるにしたがってポロシティーは減 少する傾向を示した。またての減少する傾向は真空焼成 したものの方が大きかった。

\section{5) 繫留時間と焼成雲囲気}

繫留時間と焼成雾囲気を変えた場合, 焼成後の試験片 のポロシティーがぞのように変動するかについて検討し た. 変動の様相は Table 13 と Fig. 17 亿示す. $900^{\circ} \mathrm{C}$ で大気中に备時間㢣留した試験片のポロシティーは, 大 気焼成したものと真空焼成したものとの間では有意差が
䛱められなかった。一方, 大気烍成したものでは骜留時 間を 1，3，5，7分としたもののこの順序における隣 り同志の間では有意差が認められなかったが， 1 分間㬝 留したものと 7 分間媻留したものとの間には有意差が認 められた。真空焼成したものでは㢣留時間を $1 ， 3 ， 5$ 分としたものの間には有意差が䜑められなかったが，乙 れらのものと 7 分繫留したものとの閒には有意差が認め られた。

\section{4. 走查型電顕による観察}

焼成時の収縮率およびポロシティーの測定の結果, 最 も著しい差を示した試験片について走查型電顕による観 察を行ったＦig. 18，19 は焼成温度と 焼成雲囲気を変 えた場合の焼成後の試験片の円形表面および破面におけ 


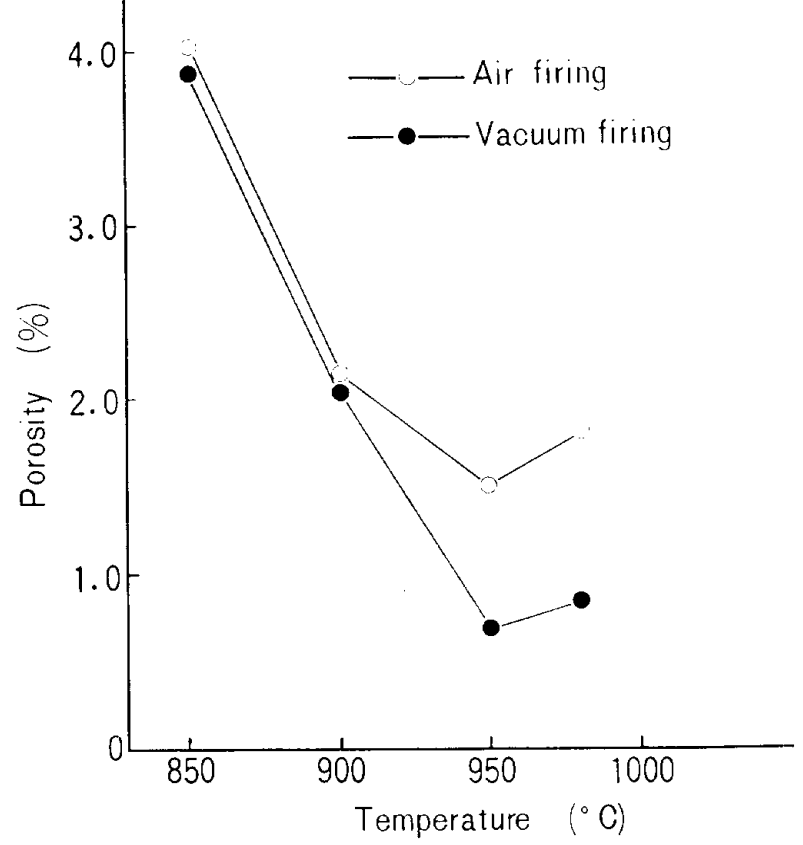

Fig. 16 Effect of firing temperature on internal porosity of fired porcelain for different firing atmosphere.

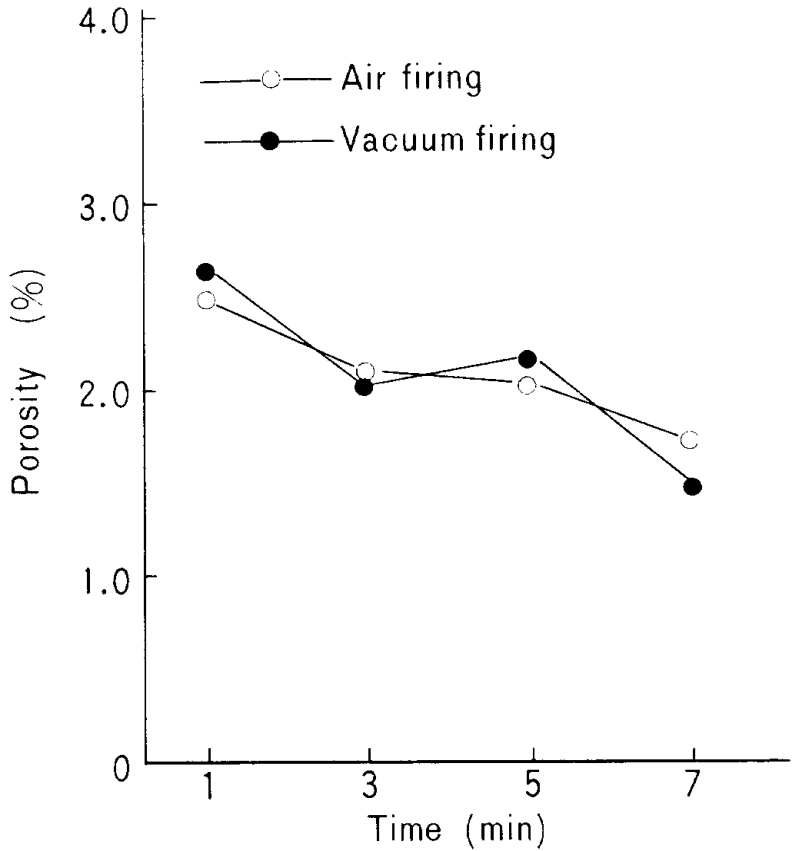

Fig. 17 Effect of holding period on internal porosity of fired porcelain for different firing atmosphere.

Table 13 Effect of holding period on internal porosity of fired porcelain for different firing atmosphere.

\begin{tabular}{|c|c|c|c|c|c|c|c|c|}
\hline & \multicolumn{2}{|r|}{ air } & \multicolumn{2}{|l|}{ firing } & \multicolumn{2}{|r|}{ vacuum } & \multicolumn{2}{|l|}{ firing } \\
\hline & $1 \min$ & $3 \mathrm{~min}$ & $5 \mathrm{~min}$ & $7 \mathrm{~min}$ & $1 \mathrm{~min}$ & $3 \mathrm{~min}$ & $5 \mathrm{~min}$ & $7 \mathrm{~min}$ \\
\hline 1 & 2.346 & 2.634 & 1.852 & 1.975 & 2.469 & 1.440 & 2.016 & 1.481 \\
\hline 2 & 2.593 & 2.410 & 2.263 & 1.358 & 2.634 & 1.605 & 1.728 & 1.811 \\
\hline 3 & 2.099 & 1.605 & 1.934 & 2.016 & 2.757 & 2.387 & 1.852 & 1.317 \\
\hline 4 & 2.757 & 1.317 & 1.934 & 2.222 & 3.210 & 2.181 & 2.634 & 1.358 \\
\hline 5 & 2.593 & 2.222 & 2.410 & 1.358 & 2.757 & 2.428 & 1.975 & 1.605 \\
\hline 6 & 2.593 & 2.510 & 1.852 & 1.481 & 2.263 & $2 \cdot 346$ & 2.798 & 1.317 \\
\hline $\mathrm{M}$ & 2.497 & 2.077 & 2.040 & 1.735 & 2.682 & 2.065 & 2.167 & 1.482 \\
\hline $\mathrm{S} \cdot \mathrm{D}$. & 0.235 & 0.495 & 0.237 & 0.380 & 0.320 & 0.431 & 0.440 & 0.197 \\
\hline
\end{tabular}

る気泡の相違を示したちのである。

真空燒成，大気焼成のいずれの場合についても，焼成 温度が高くなるにしたがって表面がなめらかになってい るととが観察された。大気焼成の場合と真空焼成の場合 との間で比較すると， $900^{\circ} \mathrm{C}$ では真空焼成したものの方 が大気焼成したものより気泡が少なく平滑な面を是して いることが羿められたが，950，980C ではその表面の 相違は認められなかった。

破面の変化については，900 $\mathrm{C}$ では真空焼成したもの
と大気焼成したものとの間に著しい差異がみられなかつ たが， $950 ， 980^{\circ} \mathrm{C}$ では真空焼成したものの方が大気焼 成したものより内部気泡が少ないことが明確に観察され た。

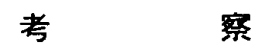

1. Void space $\%$

陶材焼成過程における収縮を最小限にとどめようとす るには，陶材生型の void space をできるだけ小さく 


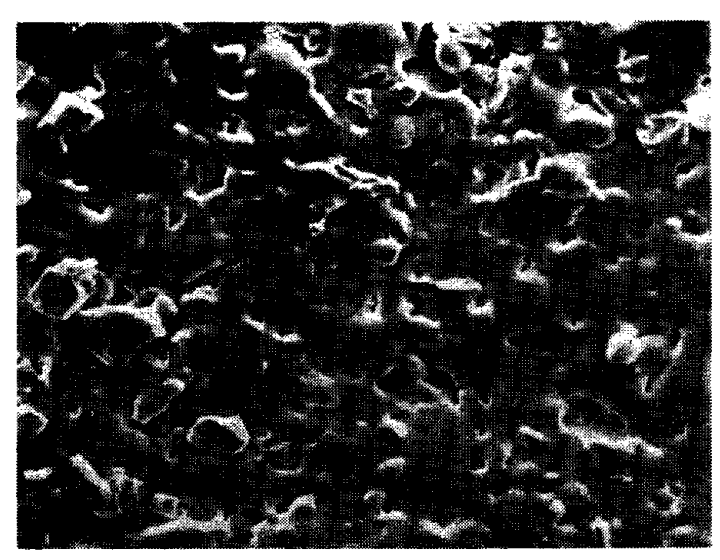

A (1) $900^{\circ} \mathrm{C}, \quad 3 \mathrm{~min}$

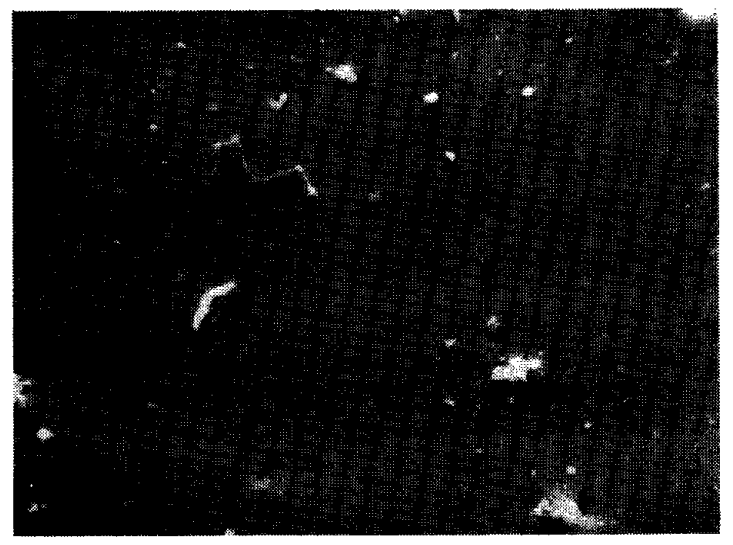

B (1) $950^{\circ} \mathrm{C}, 3 \mathrm{~min}$

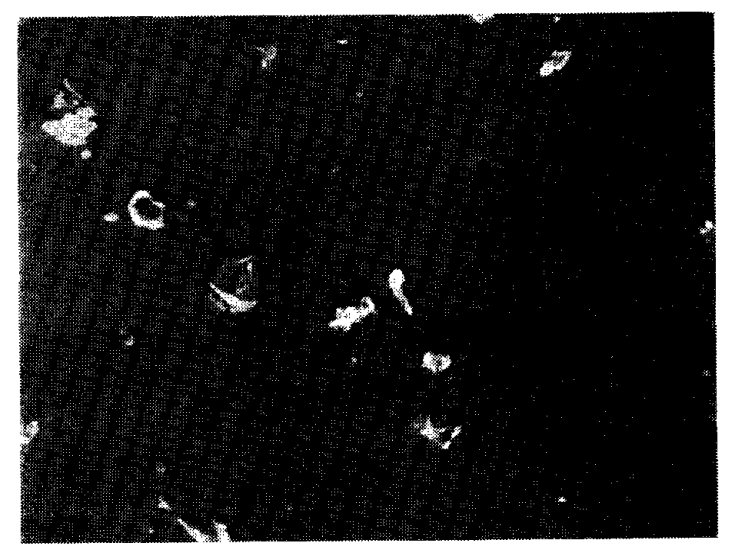

C (1) $980^{\circ} \mathrm{C}, 3 \mathrm{~min}$

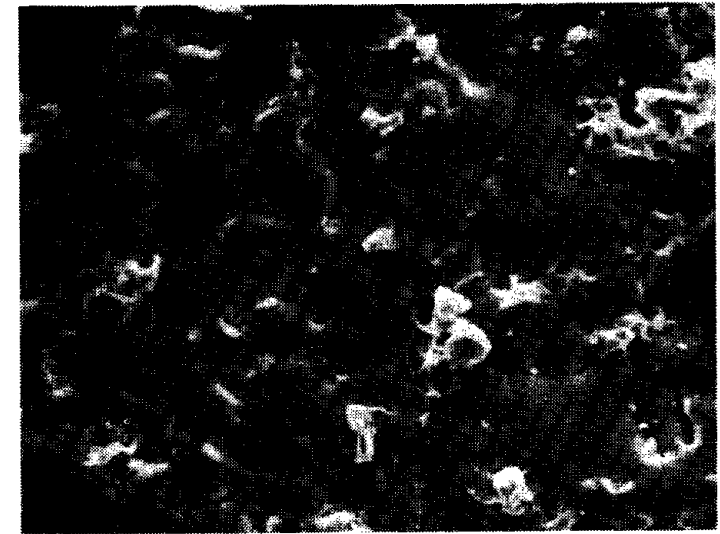

A (2) $900^{\circ} \mathrm{C}, 3 \mathrm{~min}$

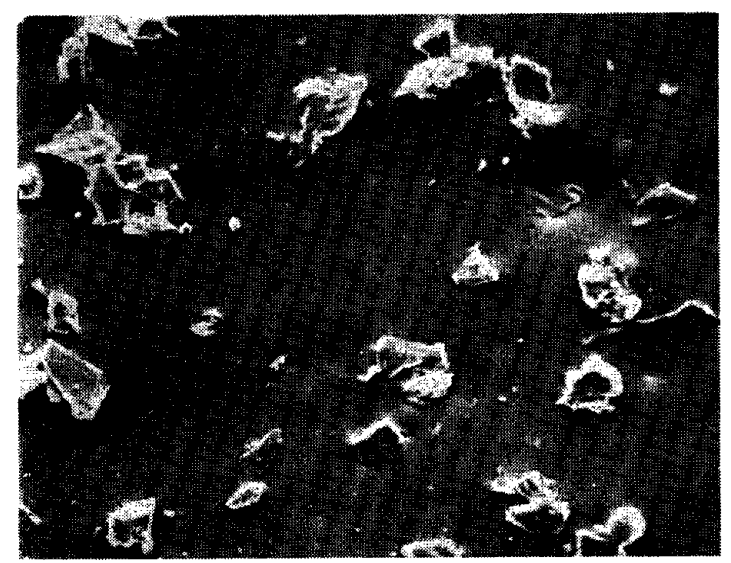

B (2) $950^{\circ} \mathrm{C}, 3 \mathrm{~min}$

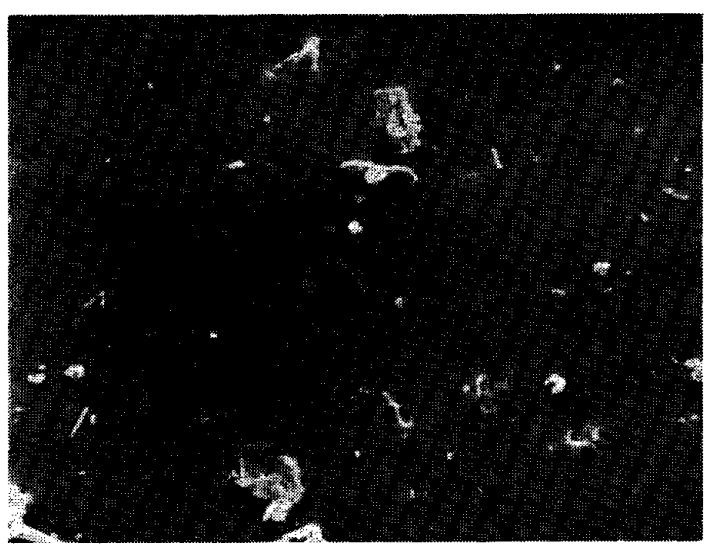

C (2) $980^{\circ} \mathrm{C}, 3 \mathrm{~min}$

Fig. 18 Surfaces of porcelain observed by SEM (Original mag. $\times 300$ ). Left three: Fired in air

Right three: Fired in vacuum 


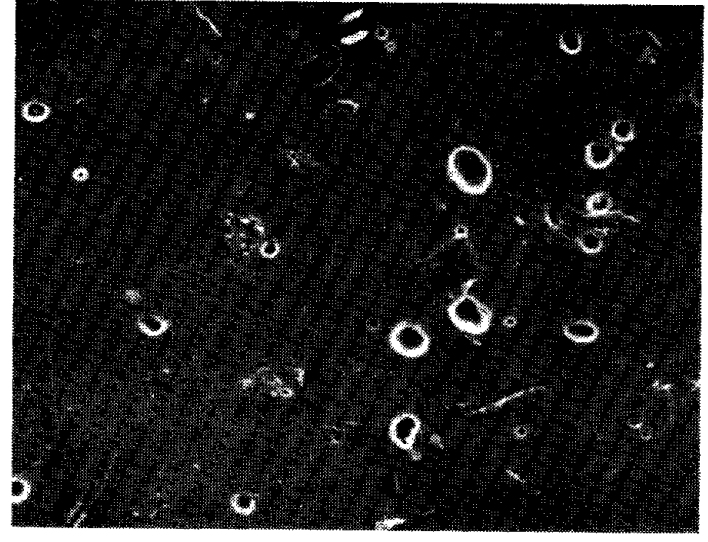

A (1) $900^{\circ} \mathrm{C}, \quad 3 \mathrm{~min}$

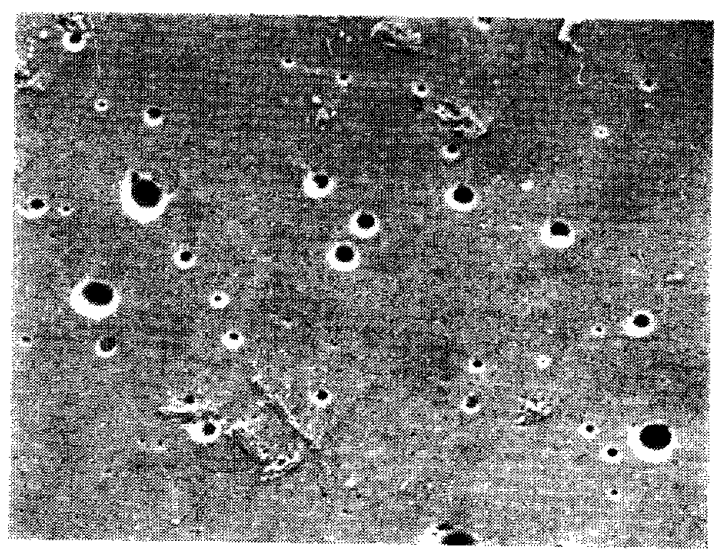

B (1) $950^{\circ} \mathrm{C}, 3 \mathrm{~min}$

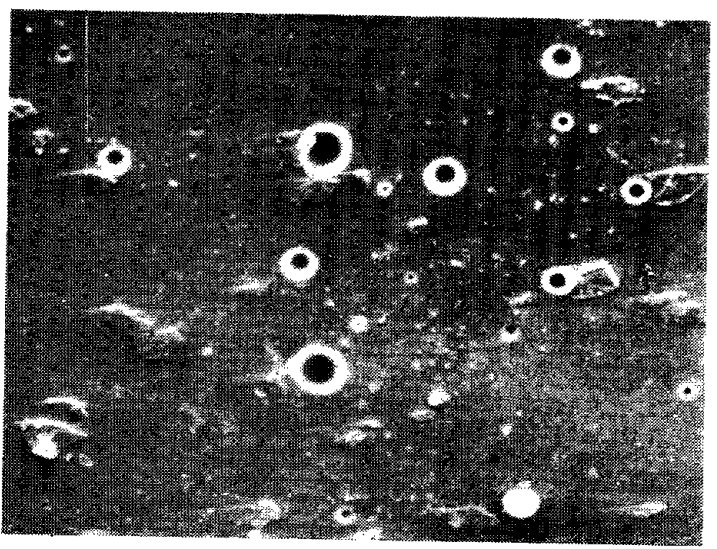

$\mathrm{C}$ (1) $980^{\circ} \mathrm{C}, 3 \mathrm{~min}$

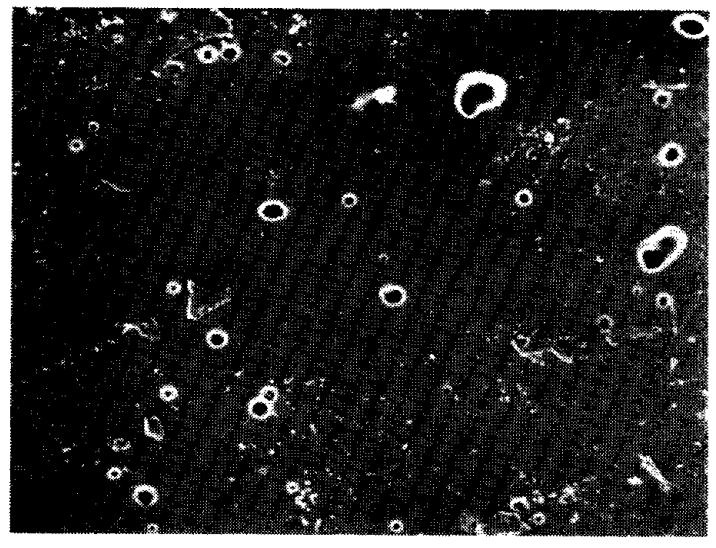

A (2) $900^{\circ} \mathrm{C}, 3 \mathrm{~min}$

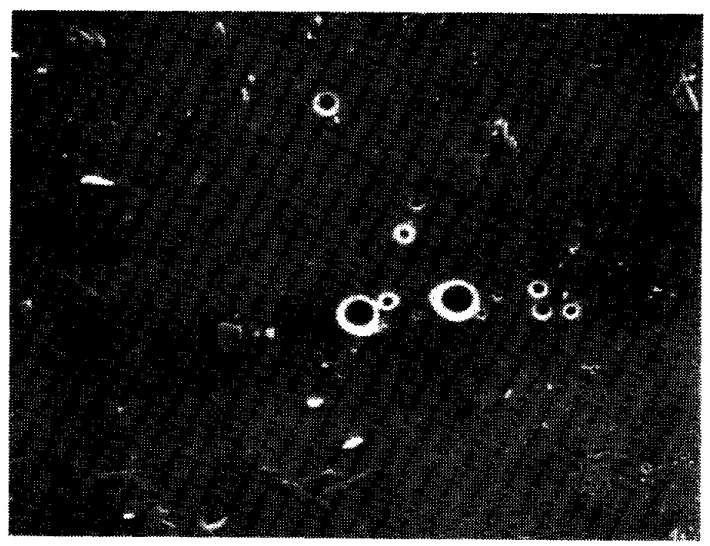

B (2) $950^{\circ} \mathrm{C}, \quad 3 \mathrm{~min}$

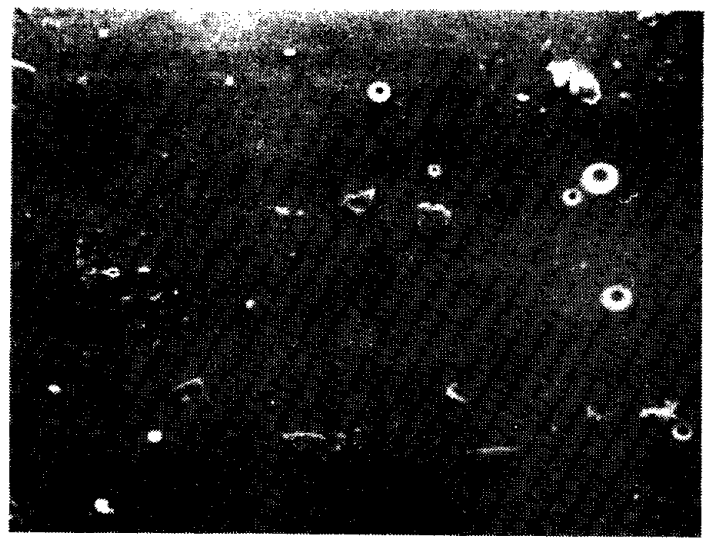

$\mathrm{C}(2) \quad 980^{\circ} \mathrm{C}, 3 \mathrm{~min}$

Fig. 19 Fracture surfaces of fired porcelain observed by SEM (Original mag. $\times 300$ ). Left three: Fired in air Right three: Fired in vacuum 
しなければならない。

現在，一般に臨床で使用されているコンデンサーは， 電磁石を利用したもの，超音波を利用したものなどであ るが，いずれの場合もその振動板に築盛体を接触させて コンデンスを行っている・しかし築盛体自体の振動はそ の大きさ，形状によって異なり，コンデンサー，振動板 の振動とは全く異った不規則な振動をしているてとが予 備実験の結果，明らかになった。したがって築盛体が吸 収したエネルギーと， void space (コンデンス効果) を明確に調バることは不可能であるが，本実験のよう に，モーターの回転を利用した振動板を用いて行ったコ ンデンスでは, 試験片の厚さが厚くなるにしたがって void space 倠增加する傾向を示した（Fig.7)，乙の ことは，築盛体の大きさ (体積) によって void space が著しく変化することを示している.同一愿さの試験片 では，モーターの振動数が多くなる（本実験では C2000 まで）にしたがって void space が小さくなっている. しかし回転数を C3000まで上げても void space に大 きな変化がみられないととから，モータ一の回転数がて の程度まで增してくると, モータ一の回転数の増加が直 接築盛体自体の振動を増大させることにはならず, 築盛 体の振動はある意味で飽和に達するものと考えられる。

2. 焼成時の収縮率

1) 試験片の厚さとコンデンス

陶材焼成過程での試験片の収縮率は, コンデンス直後 の void space が小さいものほど小さくなり，コンデ ンスの程度に依存することが観察された(Fig.8)。乙 のことは, 陶材の焼結機構, すなわち，フリット粒子の 表面が之け，void space をうめながら互いに融着し て, フリット粒子の中心部を核とした有核構造を形成す ることを考えれば当然のことといえる。

2) コンデンスと焼成雰囲気

メーカーが指示した烧成温度と熬留時間 $\left(900^{\circ} \mathrm{C}, 3\right.$ 分）で焼成雲囲気（大気，真空）だけを変えて烧成した 場合の収縮率には有意差が認められなかったが，走查型 電顕写真（Fig.18 A) では真空烧成したものの方がわ ずかに表面が滑沢になっていることが観察された。この ことから，一般に臨末で行われている真空焼成法（烧成 温度に到達したならばただちに大気圧にもどす方法）で はごく表面風の気泡だけが除去され，焼成体内部の状態 には，ほとんど影響がないものと考えられる。

3 ) 混和液とコンデンス

陶材鼬和液の影響をみると, 混和液を蒸留水とアルコ ールの 2 種類としたとき，コンデンスの程度が C 500 ,
C3000のいずれの場合にも，焼成時の試験片の仪縮率に 有意差はみられなかった（Fig，10）。陶材混和液として アルコールは缸材粉末に対するなじみがよいという特性 を持ってはいるが, 表面㲀力が蒸留水上りかなり小さい ので, 蒸留水以上に良好なコンデンス効果は得られなか ったものと思われる。

\section{4) 焼成温度と焼成雲囲気}

焼成温度を $850,900,950,980^{\circ} \mathrm{C} の 4$ 種類とし, 各 温度に 3 分間だけ繫留した場合の焼成時の収縮率を，焼 成雾团気（大気，真空）閔で比較した（Fig.11），その 結果，メーカー指示の温度 $\left(900^{\circ} \mathrm{C}\right)$ まではいずれの䨌 囲気の試験片も收縮浮の増大がみられたが，900〜980 ${ }^{\circ} \mathrm{C}$ の温度範囲では真空焼成したものだけに収縮率の增 大がみられ，大気焼成した試験片では収縮率の増大はみ られなかった。真空䊁成の場合，焼成温度が高くなる と, 融解してできるガラス質の粘度が小さくなるため, 焼成温度到達後ただちに大気圧にもどしたとしても, 脱 気泡効果が明確にあらわれて収縮率が増大したものと考 えられる。また，大気燒成の場合は，メ一カ一指示の温 度よりも焼成温度を幾分高くしても，表面層の気泡だけ が消失してグレーズ効果があらわれるのであって，燒成 体の収縮率にはほとんど影響がないものと考えられる。 このととは，各温度で焼成した試験片の表面之破面の走 查型電顕写真（Fig. 18，19）からも明らかである.

5 ）熬留時間之烧成雾团父

$1.5 \mathrm{~mm}$ 厚さの生型試験片を $900^{\circ} \mathrm{C}$ 亿達するまで加熱 してから，1，3，5，7 分間熬留した場合の収縮淬の 差を焼成霩囲気 (大気, 真空) 間で比較した（Fig.12）。 これによると，いずれの雱囲気の場合も，紫留時間が長 くなるにしたがって，收縮率のわずかな増加がみられ た。しかし，雾囲気の違いによる收縮率の差はみられな かった。とれは, メーカー指示の温度 $\left(900^{\circ} \mathrm{C}\right)$ では,

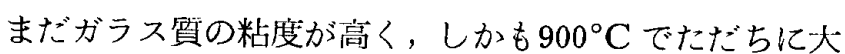
気圧にもどしたことにより焼成雲囲気の差が繫留時間を 長くしてもあらわれなかったことによるものと思われ る.

3. ポロシティー

試験片生型の厚さが増大し，コンデンス後の void space が增大すると，焼成後のポロシティーもわずか ながら増大する傾向がみられた（Fig．13）。このことか ら，厚い修復物の場合は気泡の少ない筧成体を作製する には，特に十分コンデンスするように心がけるととが必 要である。

本研究では単冠の場合を考え, 臨床的立場から, 築盛 


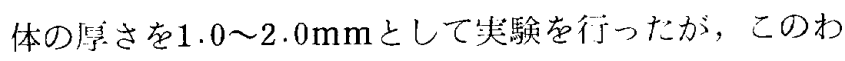

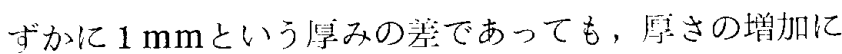
ともなう void space の増加がみられた。したがって， 築盛体が複雑（例えば多数藾にわたるブリッジ）になる 場合，現在市販されているコンデンサーを使用するかぎ り， void space（\%） に差が生じることが予想される ため，ボロシティーにもケースの違いによって叁ができ るものと考えられる。

一力焼成埧度を $900^{\circ} \mathrm{C}$ とし，その鼠度に 3 分間繋留し た場合，罗进父の違いによるボロシティーの差はみられ なかった（Fig.14：このことは，すでに些心゙た焼成時 收縮棌:の場合と间じ理由によるものと考えられる。

咧材泥の混和液とボロシティーの関係〈Fig. 15〉に

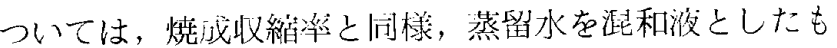
のとアルコールを泚和液としたものとの間にはポロシテ イ一の差がみられなかった。楛成温度とホロシティー

Fig.16，烧成温度に繫留した時間とホロシティー

(Fig.17）の関係についてみると，焼成時の仪維率が 大きいものほどボロジティーが小さくなっていた。

\section{結論}

大気焼成用アルミナス衡材を用いて，コンデンスの程

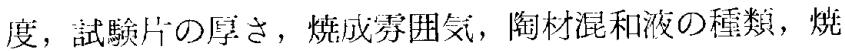
成温度, 慗留時間の相違が㜔成時の試験片の収絔枵 $\%$ および焼成後の鮧忉中のボロシティー（\%) によ゙のよう な影響を及伍すかを検討して，次のような結果を得た。

1. 当教坴で試作したコンデンサーを用いた場合，あ る範囲内（C2000まで）ではモーターの可転数が高くな るほどコンデンスの程度が進み，試験行の后さに関係な $く$ void space $\%$ ）は娍少した。

2. 試験片の字さが间じとき，コンデンスの程度によ って焼成時の臤維は 3 〜 \%程度変化したが，統計処理 の結果，その养は危唡准 $5 \%$ で有意であった。しかし烧
戌後の試験片の队部ホロシティーにはコンデンスの程度 はあまり影響を与えなかった。

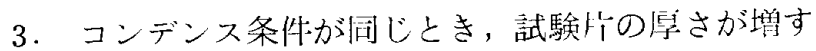
と収縮奖，ボロシティーともに增大寸る傾问がみられ た。

4. 大気焼成用缶材をメーカーの指示どおりの温度で 大気中で焼成したものと，真空中で焼成したものとの比 墸では，焼成時の収縮ならびに焼成後のボロシティーの いずれにも差基がみられなかった。

5.陶材の泥和液として蒸留水を用いた場合之蒸留水 の代りにアルコールを用いた場合とでは，試験片の焼成 收綃悴とボロシティーとのいずれにも制異がみられなか った。

6. 焼成温度の影響をみると，真空焼成の場合，焼垡 湿度が高くなると収縮率が増大し，ボロシティーは減少 した，大父焼成の場合では，メーカー指示の盜度よりも 烧成温度在幾分高くしても収縮率とボロシティーには， ほとんど変化がみられなかった。

7.いずれの焼成秀囲参の場合にも，熬留時間を長く すると収維棌はわずかに嬶大した。また，ボロシティー はわずかに娍少した。

稿を終わるにあたり，終始ご愍篤なご指導とで校閲を

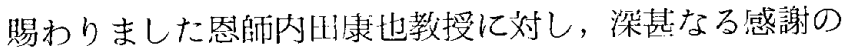
意を表するとともに，ご指隹とご校閲をいただきました 橉科理工学教空㷊一郎教授，茾上勝一郎助数授ならびに 小園凱夫講䢹に心から感謝します。また，本砄究にご協

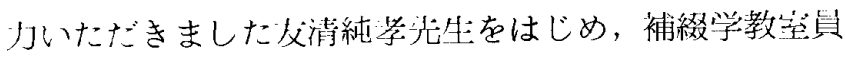
諸兄に店く御礼申しトげます。

なお，川本ロータリー米山記念奨学会および小會束口

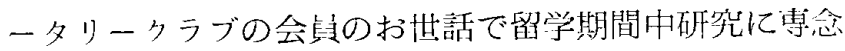
できましたことに心からの謝意を表します。

\section{文献}

1 )歯科理工学会編：歯科理工学，医四薬出版，東京，1971，304-314.

2) 井上勝一郎・小園凱夫：歯科材料 I, 㽦林出版, 果京, 1980,67 .

3 Skinner, E. W. and Phillip, R. W. : The science of dental material, W. B. Saunders Co., Philadelphia, 1967, 516-544.

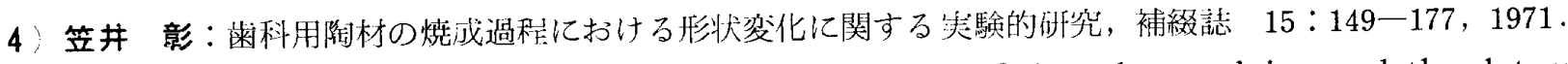

5 Klaffenbach, A. O.: A study of the factor in fusing of dental porcelain, and the determination of a fusing Chart, J.A.D.A. 26:1786-1797.

6 ）山田早苗：晶新ボーセレンテクニック，医歯浆出版，東京，1966，4-202. 
7 ) 素木洋一：わかりやすい工業用陶磁器, 技報堂, 東京, 1969, 169-176.

8 ）橋本謙一・浜野煡也：セラ之ックスの基礎, 共立出版, 東京, 1979, 285-295.

9) 追立史郎：㥻科用陶材の基礎的研究，日大米学 $47: 218-227,1973$.

10) Gill, J. R. : Pyrochemical reaction in the firing of porcelain, J. A. D. A. 18:280-290, 1931.

11) Gill, J. R. : Method and results in Condensation of dental porcelain, J. A. D. A. $19: 1147$ $-1154,1932$.

12) Clark, E. B. : Manipulation of dental porcelain, J. A. D. A. 22:33-40, 1935.

13) Skinner, E. W. and Fitzgerald, P. A. : Physical properties of dental porcelain, J.A.D.A. $25: 861-865,1938$.

14) Hodson, J. T. : Some physical properties of three dental porcelain, J. Pros. Dent. $9: 325$ $-335,1959$.

15) Baker, C. R. : Porcelain condensation and pontics, Fort, Rev. Chicago D. Soc. 19:59, 1950 ,

16) Baker, C. R. : Condensation of dental porcelain, J. Pros. Dent. 10:1094-1101, 1960 .

17) Felcher, F. R.: Dental porcelain, J. A. D. A. 19:1021, 1932.

18) Felcher, F. R.: The dental porcelain subject, Dental Cosmos 76:1266-1270, 1934.

19）松本一臣：低溶陶材の焼成と物理的性貿の研究，柬科学報 $62: 287-291,1962$.

20）友清純孝・林 恩震・他：陶材の condense と porosity, 補綴誌 $24: 543-544,1980$.

21）山北公夫・小石真純・他：粉体工学, 相書店, 東京, 1979, 85-94.

22) Kinger, W. D. : Introduction to Ceramics, John Wiley \& Sons, Inco., New York, 1960 , $414-417$.

23) Mclean, J. W. and Hugher, T. H. : The reinforcement of dental porcelain with ceramic oxides, Brit. Dent. J. $119: 251-267,1965$.

24) Semmelman, J. O. : A method of measuring porosity of porcelain teeth, J. D. Res. 36 : 945-949, 1957.

25）桂 啓文・兼子研一・他：高真空焼战による低溶陶材の物理的性質について，来材器誌３0：285一294， 1973.

26）桂 啓文・兼子研一・他：高真空焼成による高溶陶材の物理的性質について, 歯材器誌 $31 ： 84 一 94$, 1974 . 